\title{
Bioaccessibility of Some Essential Minerals in Three Selected Australian Pulse Varieties Using an in vitro Gastrointestinal Digestion Model
}

Yianna. Y. Zhang ${ }^{1}$, Joe Panozzo ${ }^{2}$, Michael. S. Hall ${ }^{3}$ \& Said Ajlouni ${ }^{1, *}$

${ }^{1}$ School of Agriculture and Food, Faculty of Veterinary and Agricultural Sciences, The University of Melbourne, Parkville, Victoria 3052

${ }^{2}$ Agriculture Victoria Research, Horsham, Victoria 3400

${ }^{3}$ Trace Analysis for Chemical, Earth and Environmental Sciences, Faculty of Veterinary and Agricultural Sciences, The University of Melbourne, Parkville, Victoria 3052

*Corresponding author: said@unimelb.edu.au

Word count of text 5104 words

Short version of title Bioavailability of minerals in pulses

Choice of journal/section

Journal of Food Science sections:

- Health, Nutrition, and Food

Previous address(es)

$\mathrm{N} / \mathrm{A}$

\section{Author disclosures}

The authors declare no conflict of interest.

[END PAGE 1]

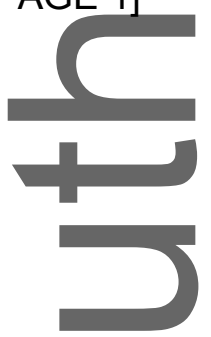

This is the ant manuscript accepted for publication and has undergone full peer review but has not been thi wo tl c copyediting, typesetting, pagination and proofreading process, which may lead to differences betw this version and the Version of Record. Please cite this article as doi: 10.1111/1750-3841.14377.

This article is protected by copyright. All rights reserved. 


\section{ABSTRACT:}

Australian produced pulse grains are exported worldwide, predominantly to developing countries where severe essential mineral deficiencies putatively subsist. An in vitro digestion model that simulates human gastric, intestinal and colonic digestion and fermentation, was used to examine the bioaccessibility of $\mathrm{Fe}, \mathrm{Mg}, \mathrm{K}, \mathrm{Ca}, \mathrm{P}, \mathrm{Zn}, \mathrm{Mn}$ and $\mathrm{Cu}$ in commercially available cultivars of Australian field pea, lentil and sweet lupin. The hull and dehulled seeds were prepared following a traditional cooking method, and quantities of bioaccessible minerals were assessed at each stage of in vitro digestion using ICP-OES elemental analyses. Results revealed that dehulled field pea (100 g dry weight) had the highest bioaccessible quantity of $\mathrm{Fe}(2.44 \pm 0.73 \mathrm{mg}), \mathrm{K}(717.10 \pm 56.66 \mathrm{mg}), \mathrm{P}(272.88 \pm 9.30 \mathrm{mg})$, $\mathrm{Zn}(1.72 .028 \pm 0.28 \mathrm{mg})$ and $\mathrm{Cu}(0.41 \pm 0.02 \mathrm{mg})$. Dehulled lupin was the best source of Mg $(138.62 \pm 1.53 \mathrm{mg})$ and $\mathrm{Mn}(1.28 \pm 0.0 .06 \mathrm{mg})$, and lentil hull showed the greatest $\mathrm{Ca}$ bioaccessible quantity $(116.33 \pm 16.73 \mathrm{mg} / 100 \mathrm{~g}$ dry weight). Additionally, the fed state digestion $(11.7 \mathrm{mg}$ bile $/ \mathrm{ml}$ sample) increased the bioaccessibility of all elements significantly $(\mathrm{P}<0.05)$ compared to fasted $(1.95 \mathrm{mg}$ bile / $\mathrm{ml}$ sample), except for $\mathrm{Zn}$ and $\mathrm{Mn}$ in lupin and lentils. These results demonstrated that dehulled seeds possess higher mineral bioaccessibility on a percentage basis compared with hulls, and that the fed state of in vitro digestion generally improved the mineral solubility significantly $(p<0.05)$.

Keywords: Bioaccessibility, Essential minerals, Legumes, Pulses, in Vitro Gastrointestinal Digestion

\section{Practical Application:}

This research aimed to assess the prospective biological accessibility of various essential elements in three commercially available Australian pulses. Results of the study provided an insight into the contents of essential minerals in Australian pulses and illustrated the 
impact of traditional cooking of dehulled pulses on these minerals bioaccessibility. These findings will provide the consumers with information about some nutritional aspects of major Australian-pulses.

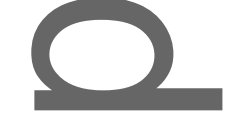

-

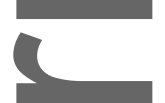

Introduction

Dietary essential minerals such as $\mathrm{Fe}, \mathrm{Mg}, \mathrm{K}, \mathrm{Ca}, \mathrm{P}, \mathrm{Zn}, \mathrm{Mn}$ and $\mathrm{Cu}$ are crucial components for various physiological processes that serve to uphold bodily functions (Gupta \& Gupta, 2014). Inadequate intake of these elements can contribute to the development of mineraldependent diseases associated with egregious monetary and intangible losses (WHO, 2010). However, mineral deficiency remains a prevalent dietary issue hindering the wellbeing of human populations worldwide, particularly in developing countries where dietary diversity is limited (Bailey, West, \& Black, 2015; Beal, Massiot, Arsenault, Smith, \& Hijmans, 2017). It has been widely documented that only a proportion of total minerals contents are released from the food matrix following digestion, and small amounts become physiologically accessible for absorption within the gastrointestinal tract (Etcheverry, Grusak, \& Fleige, 2012). Compared with animal products, minerals from plant foods are known to be less bioavailable due to the presence of anti-nutritional compounds; engendering the widespread consumption of plant-based diets as a major prevailing factor impeding global mineral sufficiency (Platel \& Srinivasan, 2016).

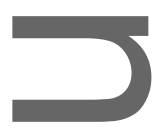

The seeds of pulses such as the field pea (Pisum sativum), sweet lupin (Lupinus angustifolius) and lentil (Lens culinaris) are deemed to be good sources of dietary essential 
minerals (Curran, 2012; Vaz Patto et al., 2015), as summarised in Table 1. Their routine consumption in diverse cultures, amalgamated with an affordable and nontoxic nature constitutes a sustainable approach to alleviate mineral deficiencies through household consumption (Fiorella, Chen, Milner, \& Fernald, 2016). Although mineral bioavailability in pulses are generally considered to be low due to the presence of anti-nutritional compounds (namely phytic acid and polyphenols) that form insoluble complexes during digestion (Alegría - Torán, Barberá - Sáez, \& Cilla - Tatay, 2015), the chemical composition of pulses can differ greatly with genetic disposition (species and cultivars), growth environment, and soil conditions (Wang \& Daun, 2006). Screening for pulse genotypes with superior mineral bioavailability is thus a promising strategy to exploit natural variation. Such approach has been successfully accomplished for $\mathrm{Zn}$ in wheat (Triticum spp.) (Welch, House, OrtizMonasterio, \& Cheng, 2005) and the common bean (Phaseolus vulgaris) (RamírezCárdenas, Leonel, Costa, \& Reis, 2010).

Existing studies on pulse mineral bioavailability are challenging to compare due to variation in the methods used (Sahuquillo, Barberá, \& Farré, 2003), and those focused particularly on Australian pulses are scarce (Karnpanit, Coorey, Clements, Benjapong, \& Jayasena, 2017). As a major exporter to developing regions including the Indian sub-continent and Middle East (Pulse Australia, 2015), there is a potential in identifying pulse genotypes appropriate for these markets. This study aimed to compare the mineral bioaccessibility of three highprotein pulses (field pea, lentil and sweet lupin) using an in vitro gastrointestinal digestion model. These three pulse cultivars Lupin (cv. Mandelup), lentil (cv. PBA Jumbo) and field pea (cv. PBA Oura) are of high yield and are available through the Australian trade market. 
To simulate the conditions in which the pulses are consumed, grains were milled and cooked using a traditional preparation method. Since the discharge of bile as a lipid-digestive agent is affected by the presence of food in the small intestine, this study also examines the effect of fasted $(0-2.5 \mathrm{mg}$ bile extract/ml digested sample) and fed states (10 and $40 \mathrm{mg}$ bile extract/ml digested sample) on mineral bioaccessibility in individual pulse components (hulls and dehulted grain) (Fu et al., 2015). Minerals were extracted at each stage of gastrointestinal digestion and quantitated using ICP-OES.

$$
\text { ( }
$$

\section{Materials and Methods}

\subsection{Plant samples}

Field pea (Pisum sativum L.) cv. Oura was sown in Rokewood, Victoria $\left(37^{\circ} 55^{\prime} 0^{\prime \prime S}\right.$ $144^{\circ} 08^{\prime} 0$ "E) on the $26^{\text {th }}$ of April, while sweet lupin (Lupinus angustifolius L.) cv. Mandelup and lentil(Lens culinaris L.) cv. Jumbo were sown in Ouyen, Victoria (3506'51"S $142^{\circ} 03^{\prime} 33^{\prime \prime} E$ ) on the $5^{\text {th }}$ and $6^{\text {th }}$ of May, 2016 respectively. The growing site characteristics are shown in Table 2 (Bureau of Meteorology, 2016). Lentil and lupin were harvested during thefirst week of December, while field pea was harvested during mid-December. A subsample of each of the three field replicates within a pulse variety was collected immediately following harvest and stored in the dark at room temperature.

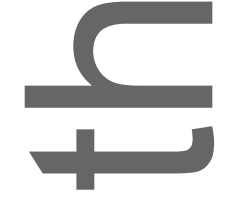

\subsubsection{Post-harvest treatment}

Each sample was dehulled and the cotyledon was split using a ICARDA splitter (International Centre for Agricultural Research in Dry Areas, Beirut, Lebanon). The dehuller/splitting equipment consists of two carborundum disks, with the bottom disk set at 
$500 \mathrm{rpm}$ and the top stationary. The gap between the two rotating discs were adjusted based on seed size. Hulls and split cotyledons were separated using an aspirator (Kimseed,-Wangara, Western Australia). Samples were then ground to a fine powder using the Perten 3100 Hammer Mill fitted with a $0.8 \mathrm{~mm}$ screen (Perten Instruments, Hägersten, Sweden), and stored in polyethylene bags until use.

\subsubsection{Reagents}

\section{$\infty$}

Bile extract (bovine), bile salts (for microbiology), guar gum, pectin, $\mathrm{CaCl}_{2}$, mucin (porcine stomach), casein (bovine), $\mathrm{NaHCO}_{3}$, L-Cysteine $\mathrm{HCl}, \mathrm{MgSO}_{4} .7 \mathrm{H}_{2} \mathrm{O}$, were purchased from Sigma-Aldrich (Castle Hill, Australia). Pepsin was acquired from Acros Organics (Morris Plains, United States). Pancreatin (porcine pancreas), nutrient broth (Oxoid®), phosphate buffered saline $(O x o i d \AA)$, plate count agar $\left(\mathrm{BD}^{\mathrm{TM}}\right.$ Difco $\left.^{\mathrm{TM}}\right)$, bacteriological peptone (L34), peptone, tryptone and yeast extract were obtained from ThermoFisher Scientific (Scoresby, Australia). Tween $80, \mathrm{NaOH}, \mathrm{NaCl}, \mathrm{KCl}, \mathrm{HNO}_{3}(70 \%)$ and $\mathrm{H}_{2} \mathrm{O}_{2}(30 \%)$ were purchased from Chem-supply (Gillman, Australia). $\mathrm{KH}_{2} \mathrm{PO}_{4}$ and $\mathrm{KOH}$ were obtained from Merck (Frenches Forest, Australia).

\subsection{Pulse slurries preparation and in vitro gastrointestinal digestion}

Ground cotyledon and hull $(2 \mathrm{~g} \pm 0.001 \mathrm{~g})$ from lentil, lupin, and field pea samples were weighed into $100 \mathrm{~mL}$ glass beakers. Each sample was mixed with tap water at ratios varying from 1:7 for field pea (Eyaru, Shrestha, \& Arcot, 2009), to 1:10 for lupin and 1:3 for lentils (Embaby, 2010; Quinteros, Farré, \& Lagarda, 2001). However, the final ratio used for 
lentils was modified to $1: 5.5 \mathrm{ml}$, as preliminary testing of the reported ratio (1:3) was insufficient to form a wet slurry. Samples were cooked on a hot plate (Haines Educational, Knoxfield, Australia) at the highest setting until the slurries thickened, yet without eye-visible colour change due to Maillard reaction products. From preliminary testing, the cooking times under these conditions were 7, 12 and $15 \mathrm{~min}$ for lentil, pea and lupin, respectively. Each pulse sample was cooked three times on the same hot plate, and slurries were then cooled to rom temperature. Cooked pulse samples were digested following the in vitro gastrointestinal model developed by Fu et al. (2015), with some modification to account for differences in sample volume and scope of this study. The original model comprises of a two-step procedure, simulating digestion environments found in the stomach and small intestine, respectively. In our study, an additional in vitro colonic fermentation step was added to the end products from intestinal digestion. All experiments were performed in triplicate, with duplicate blank samples containing $20 \mathrm{~mL}$ tap water also digested in vitro as negative controls.

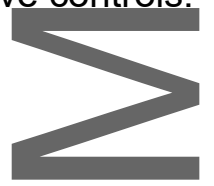

\subsubsection{Preparation of simulated gastric and intestinal fluids}

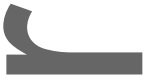

Simulated gastric and intestinal fluids were prepared according to the original model (United States Pharmacopeial Convention, 2009). For the gastric fluid, $2 \mathrm{~g}( \pm 0.01 \mathrm{~g})$ of $\mathrm{NaCl}$ and 7 $\mathrm{mL}$ of $\mathrm{HCl}(37 \%, w / v)$ were dissolved into $800 \mathrm{~mL}$ of MilliQ water, with the $\mathrm{pH}$ adjusted to 1.2 using $1 \mathrm{MNaOH}$ solution. Pepsin $(6.4 \mathrm{mg} / \mathrm{mL})$ was stirred into the solution for 15 minutes before use.
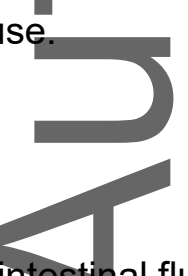

For the intestinal fluid, a solution containing $5 \mathrm{mM}$ Phosphate Buffered Saline, $0.4 \mathrm{M} \mathrm{NaCl}$ and $15 \mathrm{mM} \mathrm{CaCl}_{2}$ was prepared in Milli-Q water and adjusted to $\mathrm{pH} 6.8( \pm 0.05)$ with $1 \mathrm{M}$ 
$\mathrm{NaOH}$ and $1 \mathrm{M} \mathrm{HCl}$ (Fu et al., 2015). Prior to use, pancreatin $(10 \mathrm{mg} / \mathrm{mL})$ and bile $(0.5$ or $30 \mathrm{mg} / \mathrm{mL}$ ) were gently stirred into the solution. The two respective bile quantities are a proxy of the concentrations secreted by the gall bladder during fasting (absence of food) and fed conditions, where the range lies between 2 - $6.4 \mathrm{mM}$ for fasted and 0.5 - $37 \mathrm{mM}$ for fed (Fu et at., 2015; Holm, Müllertz, \& Mu, 2013). The selected bile concentrations used in this study were thus equivalent to final volumes of $1.95 \mathrm{mg} / \mathrm{mL}$ and $11.7 \mathrm{mg} / \mathrm{mL}$ for the fasting and fed states, respectively.

\section{(}

3.2.2. In vitro gastric and intestinal digestion

The cooked pulse slurries were transferred into $50 \mathrm{~mL}$ polypropylene tubes containing $5 \mathrm{~mL}$ of simulated gastric fluid with pepsin $(6.4 \mathrm{mg} / \mathrm{mL})$. Samples were incubated for $2 \mathrm{~h}$ at $37^{\circ} \mathrm{C}$ in a shaking incubator (ZWYR-240, Labwit Scientific, Shanghai, China) at $50 \mathrm{rpm}$.

Digestion was ceased by adjusting sample $\mathrm{pH}$ to 6.8 with $1 \mathrm{M} \mathrm{NaOH}$, where pepsin was denatured (Fuet al., 2015). The digests were centrifuged at $4500 \mathrm{rpm}(2490 \mathrm{~g})$ for 30 minutes (Jouan C3i Q5, Waltham, United States) to separate the soluble and insoluble fractions. The pulse hulls, which contained low molecular weight particles that could not be separated at such speed, were filtered using $70 \mathrm{~mm}$ ashless quantitative filter paper (No. 40, Whatman, Sigma-Aldrich, Castle Hill, Australia) to obtain the two fractions. A higher speed was not used as centrifugal force above $3000 \mathrm{~g}$ may impose unwarranted damage to plant cell walls (Terry \& Bonner, 1980), which can in turn influence mineral bioavailability (Glahn, Tako, Cichy, \& Wiesinger, 2016). The isolated soluble gastric fraction was frozen at $-20{ }^{\circ} \mathrm{C}$ for further ICP analysis.

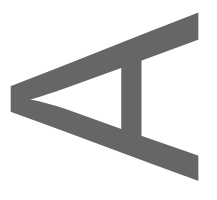


To perform the intestinal digestion at fasted and fed states, the insoluble fraction from gastric digestion was quantitatively transferred and mixed with $6.4 \mathrm{~mL}$ of simulated intestinal fluid (pH 6.8) containing pancreatin $(10 \mathrm{mg} / \mathrm{mL})$ and bile $(1.95 \mathrm{mg} / \mathrm{mL}$ and $11.7 \mathrm{mg} / \mathrm{mL}$ for the fasting and fed states, respectively) as described before. Samples were incubated for $3 \mathrm{~h}$ at $37^{\circ} \mathrm{C}$ in a shaking incubator (ZWYR-240, Labwit Scientific, Shanghai, China) at $50 \mathrm{rpm}$, and digestion terminated by placing samples in ice prior to centrifugation or filtration under the same conditions as gastric digestion. The isolated soluble intestinal fraction was also frozen at $-20^{\circ} \mathrm{C}$ for further ICP analysis. To ensure consistency through the colonic fermentation process, all insoluble fractions obtained from this step were immediately frozen at $-20^{\circ} \mathrm{C}$, until defrosted and pre-warmed to $37^{\circ} \mathrm{C}$ for colonic fermentation as a single batch.

\subsection{In vitro Colonic fermentation}

\subsubsection{Faecal culture preparation}

Human microflora that has been extracted in the same laboratory in a previous investigation (Sirisena, Ajlouni, \& $\mathrm{Ng}, 2017$ ) and maintained at $-80^{\circ} \mathrm{C}$ was used in this study. The frozen human microflora was thawed aseptically in a bacteriological cabinet, and activated using nutrient broth to prepare the stock cultures.

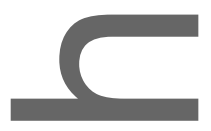

\subsubsection{Baoterial enumeration}

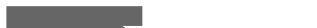

Bacterial enumeration took place prior to, and after $24 \mathrm{~h}$ of simulated colonic fermentation. For the initial enumeration, previously prepared faecal stock culture $(1 \mathrm{~mL})$ was aseptically introduced into $9 \mathrm{~mL}$ of sterile bacto-peptone $(0.1 \%)$ as the first tube of the dilution series, 
thoroughly vortexed and serially diluted again up to $10^{-8}$ in the same diluent. The same procedures were followed for samples after $24 \mathrm{~h}$ of fermentation.

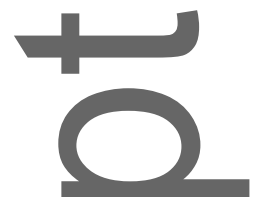

A spread plate technique was used in the bacterial enumeration, where $0.1 \mathrm{~mL}$ of selected serial dilutions was spread onto plate count agar in quadruplicate (Sanders, 2012). Half of these inoculated plates (two) were incubated aerobically, and the other half anaerobically at $37^{\circ} \mathrm{C}$ for $48 \mathrm{~h}$. The final colony counts were reported as log colony forming units/mL (Log $\mathrm{CFU} / \mathrm{mL})$.

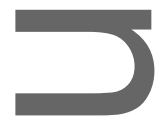

\subsubsection{Basal medium preparation}

The basal medium used for fermentation was based on the method of Dall'Erta et al. (2013) with minor adjustments. Briefly, $2.5 \mathrm{~g}$ peptone, $2.5 \mathrm{~g}$ tryptone, $2.25 \mathrm{~g}$ yeast extract, $2.25 \mathrm{~g}$ $\mathrm{KCl}, 4.5 \mathrm{~g} \mathrm{NaCl}, 2 \mathrm{~g}$ mucin, $1 \mathrm{~g}$ pectin, $1.5 \mathrm{~g}$ casein, $0.75 \mathrm{~g} \mathrm{NaHCO}_{3}, 0.4 \mathrm{~g} \mathrm{~L}-C y s t e i n e \mathrm{HCl}$, $0.62 \mathrm{~g} \mathrm{MgSO}_{4} .7 \mathrm{H}_{2} \mathrm{O}, 0.5 \mathrm{~g}$ guar gum, $0.25 \mathrm{~g} \mathrm{KH}_{2} \mathrm{PO}_{4}, 0.2 \mathrm{~g}$ bile salts, $0.55 \mathrm{~g} \mathrm{CaCl} 2$ and 0.5 $\mathrm{mL}$ Tween 80 were suspended in $500 \mathrm{~mL}$ of Milli-Q water and autoclaved at $121^{\circ} \mathrm{C}$ for 20 min (3041 VD, Thermoline Scientific, Wetherill Park, Australia). Polysaccharides (soluble starch and arabinogalactan) present in the authors' original medium were eliminated as similar carbohydrates are deemed present from the pulse intestinal digesta.

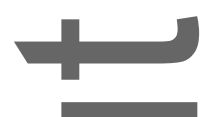

\subsubsection{Batch colonic fermentation}

The insoluble fraction remaining from each intestinal digestion replicate was weighed $(5 \mathrm{~g})$ into a $50 \mathrm{ml}$ polypropylene tube (Corning CentriStar ${ }^{\mathrm{TM}}$, ThermoFisher Scientific, Scoresby, Australia). This was inoculated with $2 \mathrm{~mL}$ of previously prepared faecal stock culture and 3 
$\mathrm{mL}$ of basal medium, both were pre-warmed to $37^{\circ} \mathrm{C}$. Tubes were flushed with $\mathrm{N}_{2}$ gas (purity 4.0, Coregas, Thomastown, Australia) before the lids were tightened and placed in anaerobic chambers with a gas-pak (AnaeroGen ${ }^{\mathrm{TM}}$, ThermoFisher Scientific, Scoresby, Australia) and an anaerobic indicator (BR0055B, ThermoFisher Scientific, Scoresby, Australia). Chambers were placed into a shaking incubator (ZWYR-240, Labwit Scientific, Shanghai, China) at $37^{\circ} \mathrm{C}$ and $50 \mathrm{rpm}$ for $24 \mathrm{~h}$.

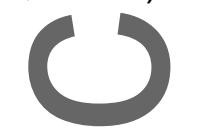

The $\mathrm{pH}$ of samples was measured (HI9124, Hanna Instruments, Keysborough, Australia) before and immediately following fermentation. Samples were then centrifuged at $8000 \mathrm{rpm}$ for $20 \mathrm{~min}$ (Jouan C3i Q5, Waltham, United States), with the soluble fraction separated and stored at $-20^{\circ} \mathrm{C}$ until processed for acid digestion and ICP analysis.

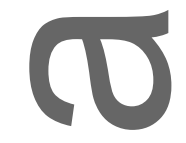

\subsection{Inductively Coupled Plasma Optical Emission Spectrometry (ICP-OES) Elemental} Analysis

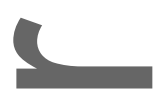

\subsubsection{Acid digestion}

All soluble (bioaccessible) fractions from in vitro digested/fermented pulse samples (gastric, intestinal and colonic) were subjected to acid digestion accordance with the closed polypropylene tube method reported by Wheal, Fowles, and Palmer (2011) with some modifications. Aliquots $(5 \mathrm{~mL})$ from each soluble gastric, intestinal and colonic digest were transferred into a $50 \mathrm{~mL}$ polypropylene tubes (227261, Greiner Bio-One $\mathrm{GmbH}$, Frickenhausen, Germany) containing $2 \mathrm{~mL}$ of $70 \% \mathrm{HNO}_{3}$ and $0.5 \mathrm{~mL}$ of $30 \% \mathrm{H}_{2} \mathrm{O}_{2}$, thoroughly vortexed, and pre-digested overnight at room temperature. Samples were again 
vortexed prior to being placed into a modified aluminium digestion block with proportionalintegral-derivative (PID) control (The University of Melbourne, Australia) for $30 \mathrm{~min}$ at $80^{\circ} \mathrm{C}$ (warming period), then gradually increased to $125^{\circ} \mathrm{C}$ for $120 \mathrm{~min}$ at $5^{\circ} \mathrm{C}$ intervals. Tube caps were loosened to equalise pressure during the initial $30 \mathrm{~min}$ at $80^{\circ} \mathrm{C}$, and tightened firmly by the end of the warming period before continuing digestion, and cooling to room temperature when completed.

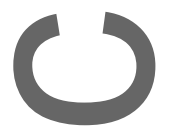

Reference pulse samples (undigested) were prepared (acid digested) to measure the total minerals present in different pulses and their hulls. This was prepared following the same procedures, except for the first step where $0.3 \mathrm{~g}( \pm 0.001)$ of the original dry ground pulse flour was used.

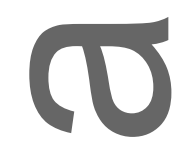

To match the $5 \% \mathrm{HNO}_{3}$ sample matrix of the calibration standards used, all samples were diluted with Milli-Q water to an acid content of $\leq 5 \%$. The volumes needed were $20.5 \mathrm{~mL}$ for samples involved in the bioaccessibility studies and $22 \mathrm{~mL}$ for reference samples (not subjected to gastrointestinal digestion). An accurate volume $(9 \mathrm{~mL})$ of each acid digested sample extract was filtered using $0.45 \mu \mathrm{m}$ syringe filters (Target2 ${ }^{\mathrm{TM}}$ Nylon, ThermoFisher Scientific, Scoresby, Australia) and transferred into $10 \mathrm{~mL}$ screw-cap polypropylene tubes (Sarstedt, Mawson Lakes, South Australia) for ICP analysis. Nitrile gloves worn during digestion were rinsed prior to use to reduce potential contamination.

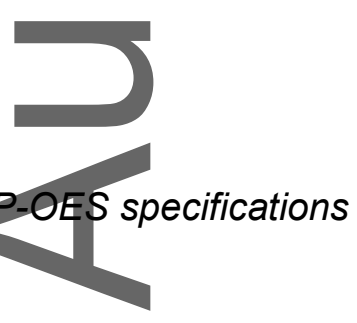

3.4.2. ICP-OES specifications 
The elemental analyses were performed using an Optima 8300 DV ICP-OES (Perkin Elmer, Glen Waverley, Australia) equipped with the syngistix for ICP 1.0 software, meinhard type K concentrio glass nebulizer, glass cyclonic spray chamber, and a radial view optical emission. The operation conditions involved power (1450 W), Ar. flow rate (15 L / min), Ar Auxiliary flow (0.2 L / min) and Ar Nebulizer flow (0.6 L / min). Samples were injected using an automated sampler (S10, Perkin Elmer, Glen Waverley, Australia). The measured elements were observed at different wavelength (Iron, 259.94; Magnesium, 285.21; Potassium, 766.49; Calcium, 317.93; Phosphorous, 213.62; Zinc, 206.2; Manganese, 257.61 and Copper $324.75 \mathrm{~nm}$ ). Calibration curves for elements were generated using multi-element standards (ICP-AM-17 and ICP-AM-12 Solution A, High-purity standards, Charleston, United States). Background correction was applied to all wavelengths (Table 4), and multiple emission lines were used to check for spectral interference. Random and targeted repeat analysis was performed to improve confidence.

\subsection{Bioaccessibility calculation}

This current study used the term bioaccessibility to refers to the fraction of mineral that was released from the examined pulses during in vitro digestion and becomes accessible (available) for absorption. Bioaccessibility should be distinguished from the term bioavailability, which is defined as the fraction of nutrients or food components that have been efficiently in vivo digested, assimilated and then absorbed in the body (FernandezGarcia et al., 2009). Consequently, it could be concluded that bioaccessibility of the studied minerals is a prerequisite for their bioavailability.

Total concentrations of $\mathrm{Fe}, \mathrm{Ca}, \mathrm{Mg}, \mathrm{Zn}, \mathrm{Se}, \mathrm{K}, \mathrm{P}, \mathrm{Cu}$ and $\mathrm{Mn}$ were quantified in the soluble (bioavailable) fraction obtained from in vitro digestion and fermentation. Bioaccessibility 
was determined using the equation proposed by Khouzam, Pohlb, and Lobinski (2011) and Sahuquillo et al. (2003);

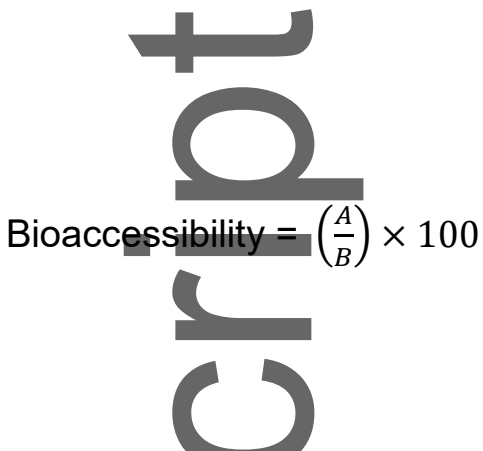

where $A$ is the concentration of the element in the bioaccessibile fraction following the threestep simulated digestion, and B is the concentration of the element in the raw, uncooked sample of equivalent weight. The minerals present in tap water and reagents were also analysed and corrected for in the final bioaccessibile fraction.

\subsection{Statistical analysis}

Total percentage bioaccessibility of the three pulses were performed using balanced (threeway) ANOVA at 95\% confidence. The three factors included pulse type, component (hull or dehulled seed) and digestion state (fasted or fed). Comparisons between the means within each pulse groupwere assessed using Fisher's least significant difference (LSD) test. All statistical analyses were carried out using Minitab 18 (Minitab Inc., Sydney, Australia).

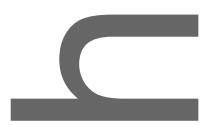

\section{Results and Discussion}

It is well known that only a small fraction of minerals in a food, particularly those plant-based are readily available for absorption by the human body (Platel \& Srinivasan, 2016). To our knowledge, this is the first systematic study that compares the bioaccessibility of multiple essential minerals in the major components of different Australian-grown pulses, using in 
vitro gastrointestinal digestion. In addition, the study quantified and compared essential minerals in two primary components of the seed: the dehulled cotyledon/embryo and seed coat. It should be noted also that tap water was used during cooking of these pulses in order to mimic home practices. However, mineral contents in tap water should not affect the results, or the aims of this investigation, since all experiments included duplicate blank samples containing $20 \mathrm{~mL}$ tap water as negative controls (slurries preparation, section 3.2).

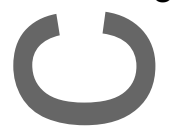

\subsection{Mineralcontents in raw pulses}

The absolute contents $(\mathrm{mg} / 100 \mathrm{~g}$ dry weight $=\mathrm{dwt}$.) of eight essential minerals $(\mathrm{Fe}, \mathrm{Mg}, \mathrm{K}$, $\mathrm{Ca}, \mathrm{P}, \mathrm{Zn}, \mathrm{M}$, and $\mathrm{Cu}$ ) in both pulse cotyledon and hulls are shown in Table 3. These data revealed that pulse hulls generally contained greater amounts of Ca relative to its dehulled counterparts, with 5.74-fold more in lupin, 12.93 in lentil and 13.18 in field pea. On the contrary, hulls contained less amounts of $\mathrm{P}, \mathrm{Mn}$ and $\mathrm{Zn}$ in comparison with the cotyledon (dehulled pulses). For example, the average $\mathrm{K}$ contents in lupin cotyledon and hull were $1007.75 \pm 46.61$ and $393.48 \pm 31.79 \mathrm{mg} / 100 \mathrm{~g} \mathrm{dwt}$, respectively. All other tested minerals ( $\mathrm{Fe}, \mathrm{Zn}, \mathrm{Mn}$ and $\mathrm{Cu}$ ) were present in very small quantities in both hull and cotyledon of all pulses. Cu contents in all tested pulses were the smallest in comparison with all other minerals and was below the detection limit $(<0.003 \mathrm{mg} / 100 \mathrm{~g} \mathrm{dwt.})$ in lupin hull.

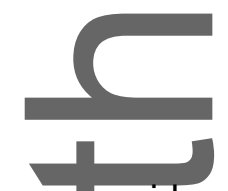

Hulls are considered mostly as a fibrous fraction of the seeds (Tosh \& Yada, 2010). Data in the literature regarding the mineral content in hulls are very limited as pulses are typically analysed as the whole or dehulled seed (Sparvoli, Bollini, \& Cominelli, 2015; Wang, Hatcher, Tyler, Toews, \& Gawalko, 2010). Among the studies of hulls and de-hulled seeds was the investigation by Hove (1974) in New Zealand. The author reported that the amounts of Mn, 
$\mathrm{Zn}, \mathrm{Cu}$ and $\mathrm{Fe}$ in hulls of a sweet lupin cultivar were $1.7,3.7,0.89$ and $6.5 \mathrm{mg} / 100 \mathrm{~g} \mathrm{dwt}$, respectively. However, results from this current investigation revealed that sweet lupin hull contained significantly greater amount of $\mathrm{Mn}(4.49 \pm 0.01 \mathrm{mg} / 100 \mathrm{~g} \mathrm{dwt})$, similar amount of $\mathrm{Zn}(3.05 \pm 0.80 \mathrm{mg} / 100 \mathrm{~g} \mathrm{dwt})$, and significantly smaller quantities of $\mathrm{Cu}$ (below detection limit) and $\mathrm{Fe}(3.28 \pm 082 \mathrm{mg} / 100 \mathrm{~g} \mathrm{dwt})$ (Table 3). These variations in the detected amounts of minerals may be attributed to the usage of different instruments in the analysis (atomic absorption spectroscopy versus ICP-OES) along with other variables including lupin cultivar andgrowth conditions.

Another study in the United States by Ariza-Nieto, Blair, Welch, and Glahn (2007), on mineral content in the hull of common bean (Phaseolus vulgaris) showed a wide range of $\mathrm{Fe}$ content $(3-15.6 \mathrm{mg}$ per $100 \mathrm{~g} \mathrm{dwt})$, which is close to the range obtained in this current investigation of the hull from three different pulses [(3.28 (lupin) $-8.99 \mathrm{mg} / 100 \mathrm{~g} \mathrm{dwt}$ field pea)].

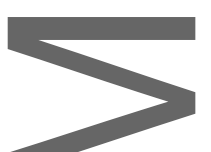

The concentrations of tested minerals (Table 3) in the dehulled seeds (cotyledon) were found to be within the range of those reported in the literature for field pea, sweet lupin and green lentil The minerals content in dehulled lupin, lentils and field pea were $4.38 \pm 0.55$, $5.50 \pm 0.52$ and $5.65 \pm 0.99 \mathrm{mg} / 100 \mathrm{~g}$ dwt for Fe; $1007.75 \pm 46.61,969.65 \pm 45.34$ and $1111.18 \pm 28.57 \mathrm{mg} / 100 \mathrm{~g} \mathrm{dwt}$ for $\mathrm{K}$; and $0.55 \pm 0.01,0.4 \pm 0.1$ and $0.55 \pm 0.04 \mathrm{mg} / 100 \mathrm{~g}$ dwt, for Cu, respectively. Compared with dehulled lentil and field pea, dehulled lupin was found to be a particularly good source of $\mathrm{Mg}(217.46 \pm 13.78)$, Ca $(113.56 \pm 20.5)$ and $\mathrm{Mn}$ $(5.03 \pm 0.43 \mathrm{mg} / 100 \mathrm{~g} \mathrm{dwt})$. The $\mathrm{K}$ content of dehulled field pea $(1111.18 \pm 28.57 \mathrm{mg} / 100 \mathrm{~g}$ dwt) (Table 3) was greater than the range reported in the literature $(920.5-966.5 \mathrm{mg} / 100 \mathrm{~g}$ dwt) for Canadian grown dehulled pea (Wang, Hatcher, \& Gawalko, 2008). Similarly, minerals contents in dehulled lupin, Ca (113.56 \pm 20.5$), \mathrm{Zn}(4.86 \pm 0.95)$ and Fe (4.38 \pm 
0.55) were greater than those reported by Karnpanit et al. (2017) $(90.66,2.05$ and 3.50 $\mathrm{mg} / 100 \mathrm{~g}$ dwt, respectively).

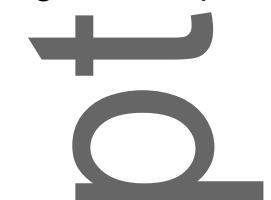

\subsection{Mineral bioaccessibility}

Since mineral solubility is a prerequisite for absorption (Etcheverry et al., 2012), results from this study present the maximum percentage of each element that is released from the food matrix following cooking and in vitro gastrointestinal digestion. The reported literature on the minerals bioavailability from pulses, have focused mainly on Fe and $\mathrm{Zn}$ and their deficiencies (Platel \& Srinivasan, 2016). Investigations of other essential elements often overlooked (Khouzam et al., 2011; Lagarda, Cilla, \& Barbera, 2016). Additionally, discrepancies in the bioavailability assessment methodologies used can generate varying results due to systematic differences (Drago, 2017; Sahuquillo et al., 2003). Unsimilar to the in vitro reported studies which involved mainly gastric and intestinal digestion (Etcheverry et al, 2012), this current investigation examined all three steps of gastrointestinal digestion including the step of colonic fermentation.

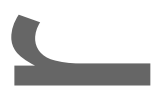

The total percentage bioaccessibility of $\mathrm{Fe}, \mathrm{Mg}, \mathrm{K}, \mathrm{Ca}, \mathrm{P}, \mathrm{Zn}, \mathrm{Mn}$ and $\mathrm{Cu}$, as well as the amount released during each of the three digestion steps are shown in Tables 4, 5, 6, 7, 8, 9, 10 and 11, respectively. The highest overall total percentage bioaccessibility was found in $\mathrm{Cu}$ (up to $80 \%$, field pea) (table 11), and the lowest in Fe $(0.1 \%$, lentil hull) (Table 4$)$. The individual bioaccessibility values for various tested minerals ranged from 0.1 to $45.13 \%$ (Fe), 31.21 to $74.19 \%(\mathrm{Mg}), 13$ to $61.87 \%(\mathrm{~K}), 9.98$ to $52.68 \%(\mathrm{Ca}), 12.67$ to $68.32 \%(\mathrm{P}), 0.35$ to $39.38 \%(\mathrm{Zn}), 0.35$ to $69.21 \%(\mathrm{Mn})$, and 49.91 to $80.08(\mathrm{Cu})$. The data revealed that mineral bioaccessibility varied among the tested pulses. For examples, field pea released the 
highest bioaccessibile Fe (45.13\%, Table 4), Mg (74.19\%, Table 5), P (68.32\%, Table 8), Zn (37.55\%, Table 9) and $\mathrm{Cu}(80.08 \%$, Table 11$)$, Lupin was the best source of b bioaccessibile K $(61.87 \%$, Table 6$)$ and lentils had the highest \% bioaccessibile Mn (69.21\% Table 10$)$.

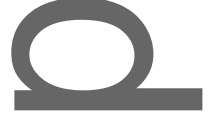

口

Data revealed significant $(P<0.05)$ three-way interactions between the pulse type, component (Hull and Cotyledon), and digestion state for all elements except $\mathrm{Mg}$ and $\mathrm{Ca}$, indicating that the three factors are multiplicative in determining the total bioaccessibility. With all tested elements, the pulse type alone displayed a significant $(P<0.05)$ effect on the bioaccessibility of each element with the hulls exhibiting considerably lower bioaccessibility than dehulled pulses (Tables 4 to 11). Additionally, the fed state of digestion (11.7 $\mathrm{mg}$ bile /ml sample) generally increased the bioaccessibility of elements significantly $(P<0.05)$ compared to fasted (1.95 mg bile / $\mathrm{ml}$ sample) except for $\mathrm{Zn}$ in lupin and lentils (Table 9) and $M n$ in lupin and lentils (Table 10$)$ where the fasted state showed significantly $(P>0.05)$ greater bioaccessibility. This increase in mineral bioavailability with higher bile concentrations may be due to the formation of bile-mineral soluble complexes, which become more available (Sitrin, 2014).
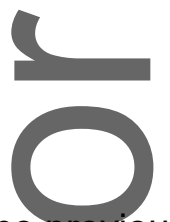

Most of the previously reported studies on minerals bioavailability focused on 2-3 elements and investigated the effect of gastric and intestinal digestion only. For example, Singh, Prasad, and Aalbersberg (2016) applied the in vitro gastrointestinal digestion to examined the bioavailability of Fe and $\mathrm{Zn}$ only. This current investigation examined the bioaccessibility of eight elements ( $\mathrm{Fe}, \mathrm{Mg}, \mathrm{K}, \mathrm{Ca}, \mathrm{P}, \mathrm{Zn}, \mathrm{Mn}$ and $\mathrm{Cu}$ ) during the gastrointestinal digestion and colonic fermentation. As anticipated, including the colonic fermentation improved mineral bioaccessibility via the release of more minerals during 
fermentation. For example, the bioaccessibility of Fe from in vitro gastrointestinal fed state digestion of dehulled and hull lupin reached $10.82 \pm 1.2$ and $\% 3.27 \pm 0.5 \%$, respectively. Adding these two values revealed a total Fe bioaccessibility from both dehulled and hull lupin during fed gastrointestinal digestion of $14.09 \%$ (Table 4), which is similar to the $\%$ bioavailability of Fe from pulses as reported by Singh et al. (2016). However, adding the amount of bioaccessibile Fe from the colonic fermentation of dehulled $(13.2 \pm 0.95)$ and hull lupin $(4.71 \pm 1.4 \%$ ) will bring the total bioaccessible Fe to $32.00 \%$, which is much larger than the gastric bioavailable value (14.4\%) reported by Singh et al. (2016). Similarly, the total bioaccessibility of $\mathrm{Zn}$ from both hull and dehulled lupin (fed state) detected in this current study reached $(25.50 \%)$ (Table 9$)$, which is much greater than the value $(4.02 \%)$ reported by Singh et al. (2016).

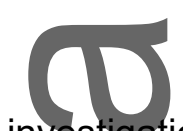

Another investigation by Das, Raghuramulu, and Rao (2005) revealed that the \% ionisable iron (bioavailable) in whole pea was $35.66 \pm 4.44 \%$, which was similar to the average value of $37.31 \%$ for pea cotyledons detected in this study. It is interesting to observe this resemblance in bioaccessibility, despite differences among the tested cultivars, the methods of sample preparation and extraction, the presence of hulls, and the machine used in mineral quantitation.

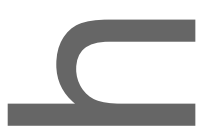

Results from this current study revealed also that bioaccessibility of several elements (namely $\mathrm{Fe}, \mathrm{K}, \mathrm{Ga}, \mathrm{P}$ and $\mathrm{Zn}$ ), was very small to no discernible quantities $(<0.1 \%)$ during intestinal digestion, while larger quantities of these mineral were absorbed in the colon. These findings were in agreement with (Blaine, Chonchol, \& Levi, 2014; Gropper, 2008; Khanal, 2008), who reported main absorption of $\mathrm{Ca}, \mathrm{Mg}$ and $\mathrm{K}$ in the human colon. The 
small bioavailable fractions of minerals during intestinal digestion may partially explain why Fe from pulses continue to show poor bioavailability in human studies, even in anaemic individuals where absorptive mechanisms are upregulated (DellaValle, Glahn, Shaff, \& O'Brien, 2015; Petry et al., 2012). As pulse hulls are known to contain up to $90 \%$ of the phenolic compounds (Dueñas, Hernández, \& Estrella, 2002; Ramdath \& Tsao, 2012), the poor bioavailability of Fe and other cations may be attributed to the formation of insoluble complexes by polyphenols during intestinal digestion, as polyphenols are good chelators of both $\mathrm{Fe}^{2+}$ and $\mathrm{Fe}^{3+}$ (Bouglé, 2013). However, further studies are required to confirm whether the colon can facilitate the absorption of minerals other than $\mathrm{Ca}, \mathrm{Mg}$ and $\mathrm{K}$, where some elements (e.g. $\mathrm{Zn}$ ) have been shown promise in animal studies to be absorbed through the colon(Gopalsamy et al., 2015).

The study's outcome supports the recurring notion that due to quantity and distribution differences in the pro- and anti-nutritional factors in pulses, higher mineral concentrations do not always correlate with higher bioavailability (Karnpanit et al., 2017; Sahuquillo et al., 2003). This pattern of poor correlation was particularly evident for Fe in the hulls, where percentage bioaccessibility was consistently lower than their dehulled counterparts, despite possessing higher concentrations. This observation was not an issue for $\mathrm{Mg}$, since nutritionally significant amounts of $\mathrm{Mg}(42.3 \%, 49.66 \%$ and $36.44 \%)$ were still bioaccessibile in the hulls of lupin, lentils and field pea pulses (fed state), respectively (Table 5). In comparison, low levels of total Fe bioaccessibility $(<0.1 \%)$ was found in the lentil hull compared with $42.33 \pm 2.3 \%$ in dehulled lentil (Table 4), regardless of encompassing more Fe in lentil hull $(6.99 \pm 0.79 \mathrm{mg} \mathrm{dwt})$ compared with its dehulled counterpart $(5.50 \pm 0.52$ $\mathrm{mg} / 100 \mathrm{gdwt}$ ) (Table 3). Consequently, it should be recommended that dehulled seeds should be consumed where maximal Fe and Mg bioaccessibility is desired. Similarly, the 
lentil hull contains significantly $(P<0.05)$ larger quantity of Ca $(427.46 \pm 40.52 \mathrm{mg} / 100 \mathrm{~g} \mathrm{dwt})$ than dehulled lentils $(33.07 \pm 5.15 \mathrm{mg} / 100 \mathrm{~g} \mathrm{dwt})$ (Table 3$)$, however, only small percentage $(27.23 \pm 0.8 \%)$ of lentil hull Ca was bioaccessibile in comparison with $52.68 \pm 0.9 \%$ from dehulled lentil (Table 7). Considering the fact that lentils hull contains a huge amount of $\mathrm{Ca}$ $(427.46 \pm 40.52 \mathrm{mg} / 100 \mathrm{~g} \mathrm{dwt})$, even the relatively small percentage bioaccessibility $(27.23 \pm$ $0.8 \%$ ) will endow a decent amount of dietary $\mathrm{Ca}$, despite having low Fe and moderately low Mg bioaccessibility.

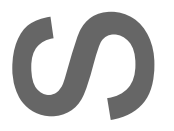

\section{Conclusion}

The presentstudy confirmed previous suggestions that pulses with high essential mineral content do not always possess greater minerals bioaccessibility. Comparing the three examined pulses, it can be concluded that field pea cultivar contained the highest bioaccessible quantity of $\mathrm{Fe}, \mathrm{Mg}, \mathrm{P}, \mathrm{Zn}$ and $\mathrm{Cu}$. Lupin was the best source of $\mathrm{K}$ and $\mathrm{Ca}$, and lentil hull contained the most Ca. While dehulling the seed appears to improve the in vitro bioaccessibility of most elements, it must be noted that some loss of minerals is expected, particularly for Ca. Results of digested fractions suggested a prevailing factor of low mineral bioaccessibility in pulses. The severe and common known deficiency of some minerals, such as Fe and $\mathrm{Zn}$ can be attributed to the low bioavailable fraction found at the site of absorption. Though this is likely to be a result of anti-nutritional compounds that form insoluble complexes, further studies are required to confirm this. In vivo studies for elements found in the soluble fractions would also improve the current understanding of essential mineral bioavailability.

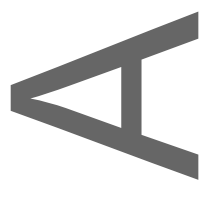




\section{Acknowledgments}

The authors would like to thank Dr. Jason Brand for providing the pulse samples. We also appreciate Michelle Rhee, Sameera Sirisena, Pamu Kularathna, Martin Ji, Veradina

Dharjono and Johnathan $\mathrm{Vu}$ for their technical support within the laboratory.

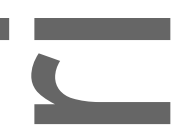

\section{Author Contributions (required for JFS original research manuscripts)}

All authors have contributed to the planning and coordination of this study. Y.Y. Zhang was responsible for the laboratory work and drafting the manuscript under the supervision of $\mathrm{S}$. Ajlouni and J. Panozzo. M.S. Hall performed the ICP-OES analyses, and assisted in the interpretation of the final ICP results.

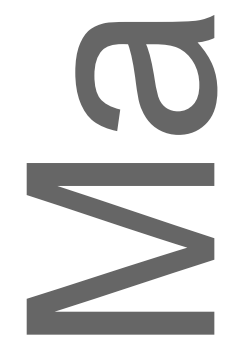

\section{References}

Alegría - Torán, A., Barberá - Sáez, R., \& Cilla - Tatay, A. (2015). Bioavailability of minerals in foods. In M. G. de la Guardia, S (Ed.), Handbook of Mineral Elements in Food (pp. 41-63). Hoboken: Wiley Blackwell.

Ariza-Nieto, M., Blair, M. W., Welch, R. M., \& Glahn, R. P. (2007). Screening of Iron Bioavailability Patterns in Eight Bean (Phaseolus vulgaris L.) Genotypes Using the Caco-2 Cell in Vitro Model. Journal of Agricultural and Food Chemistry, 55(19), 7950-7956. doi:10.1021/jf070023y

Bailey, R. L., West, K. P., \& Black, R. E. (2015). The epidemiology of global micronutrient deficiencies. Annals of Nutrition \& Metabolism, 66(S2), 55-66.

Beal, T., Massiot, E., Arsenault, J. E., Smith, M. R., \& Hijmans, R. J. (2017). Global trends in dietary micronutrient supplies and estimated prevalence of inadequate intakes. PLOS ONE, 12(4), e0175554. doi:10.1371/journal.pone.0175554 
Blaine, J., Chonchol, M., \& Levi, M. (2014). Renal Control of Calcium, Phosphate, and Magnesium Homeostasis. Clinical Journal of the American Society of Nephrology. doi:10.2215/cjn.09750913

Bouglé, D. (2013). Chapter 23 - Tea and Iron Metabolism A2 - Preedy, Victor R. In Tea in Health and Disease Prevention (pp. 275-287): Academic Press.

Bureau of Meteorology. (2016). Climate Data Online Database (Ouyen Walpeup Research \& Rokewood Sheoaks VIC). Retrieved from http://www.bom.gov.au/climate/data/

-

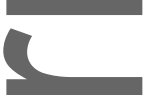

Chakravaty, A. M., A.S.; Ramaswamy, H.S. (2003). Handbook of Postharvest Technology: Cereals, Fruits, Vegetables, Tea, and Spices. New York: Marcel Dekker.

Curran, J. (2012). The nutritional value and health benefits of pulses in relation to obesity, diabetes, heart disease and cancer. British Journal of Nutrition, 108(S1), S1-S2. doi:10.1017/S0007114512003534

Dall'Erta, A.,Cirlini, M., Dall'Asta, M., Del Rio, D., Galaverna, G., \& Dall'Asta, C. (2013). Masked Mycotoxins Are Efficiently Hydrolyzed by Human Colonic Microbiota Releasing Their Aglycones. Chemical Research in Toxicology, 26(3), 305-312. doi:10.1021/tx300438c

Das, P., Raghuramulu, N., \& Rao, K. (2005). Determination of in vitro availability of iron from common foods. J. Hum. Ecol, 18(1), 13-20.

DellaValle, D. M., Glahn, R. P., Shaff, J. E., \& O’Brien, K. O. (2015). Iron Absorption from an Intrinsically Labeled Lentil Meal Is Low but Upregulated in Women with Poor Iron Status. The Journal of Nutrition, 145(10), 2253-2257. doi:10.3945/jn.115.217273

Drago, S. R. (2017). Chapter 5 - Minerals A2 - Galanakis, Charis M. In Nutraceutical and Functional Food Components (pp. 129-157): Academic Press.

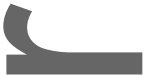

Dueñas, M., Hernández, T., \& Estrella, I. (2002). Phenolic composition of the cotyledon and the seed coat of lentils (Lens culinaris L.). European Food Research and Technology, 215(6), 478-483. doi:10.1007/s00217-002-0603-1

Embaby, H.E.-S. (2010). Effect of soaking, dehulling, and cooking methods on certain antinutrients and in vitro protein digestibility of bitter and sweet lupin seeds. Food Science and Biotechnology, 19(4), 1055-1062. doi:10.1007/s10068-010-0148-1

Etcheverry, P., Grusak, M. A., \& Fleige, L. E. (2012). Application of in vitro bioaccessibility and bioavailability methods for calcium, carotenoids, folate, iron, magnesium, polyphenols, zinc, and vitamins B6, B12, D, and E. Frontiers in Physiology, 3(317), 1-22.

This article is protected by copyright. All rights reserved. 
Eyaru, R., Shrestha, A. K., \& Arcot, J. (2009). Effect of various processing techniques on digestibility of starch in Red kidney bean (Phaseolus vulgaris) and two varieties of peas (Pisum sativum). Food Research International, 42(8), 956-962. doi:10.1016/j.foodres.2009.06.007

Fernández-Garcia, E., Carvajal-Lérida, I., \& Pérez-Gálvez, A. (2009). In vitro bioaccessibility assessment as a prediction tool of nutritional efficiency. Nutrition Research, 29, 751760

Fiorella, K. J., Chen, R. L., Milner, E. M., \& Fernald, L. C. H. (2016). Agricultural interventions for improved nutrition: A review of livelihood and environmental dimensions. Global Food Security, 8, 39-47.

Fu, S., Augustin, M.A., Shen, Z., Ng, K., Sanguansri, L., \& Ajlouni, S. (2015). Bioaccessibility of curcuminoids in buttermilk in simulated gastrointestinal digestion models. Food Chemistry, 179, 52-59.

doi:10.1016/j.foodchem.2015.01.126

Glahn, R. P., Tako, E., Cichy, K., \& Wiesinger, J. (2016). The Cotyledon Cell Wall and Intracellular Matrix Are Factors That Limit Iron Bioavailability of the Common Bean (Phaseolus vulgaris). Food \& Function, 7, 3193-3200.

Gopalsamy, G. L., Alpers, D. H., Binder, H. J., Tran, C. D., Ramakrishna, B. S., Brown, I., . . Young, G. P. (2015). The Relevance of the Colon to Zinc Nutrition. Nutrients, 7(1), 572-583. doi:10.3390/nu7010572

Gropper, S. S. S., J.L., Groff, J.L. (2008). Advanced Nutrition and Human Metabolism. Belmont: Cengage Learning.

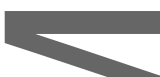

Gupta, U. C., \& Gupta, S. C. (2014). Sources and Deficiency Diseases of Mineral Nutrients in Human Health and Nutrition: A Review. Pedosphere, 24(1), 13-38. doi:10.1016/S1002-0160(13)60077-6

Holm, R., Müllertz, A., \& Mu, H. (2013). Bile salts and their importance for drug absorption. International Jourhal of Pharmaceutics, 453(1), 44-55. doi:10.1016/j.ijpharm.2013.04.003

Hove, E. L. (1974). Composition and protein quality of sweet lupin seed. Journal of the Science of Food and Agriculture, 25(7), 851-859. doi:10.1002/jsfa.2740250715

Karnpanit, W., Coorey, R., Clements, J., Benjapong, W., \& Jayasena, V. (2017). Calcium, Iron, and Zinc Bioaccessibilities of Australian Sweet Lupin (Lupinus angustifolius L.) Cultivars. Journal of Agricultural and Food Chemistry, 65(23), 4722-4727. doi:10.1021/acs.jafc.7b00445

Khanal, R.C.N., I. (2008). Regulation of Intestinal Calcium Transport. Annual Review of Nutrition, 28(1), 179 196. doi:10.1146/annurev.nutr.010308.161202

Khanam, A., \& Platel, K. (2016). Influence of domestic processing on the bioaccessibility of selenium from selected food grains and composite meals. Journal of Food Science and Technology, 53(3), 16341639. doi:10.1007/s13197-015-2075-x

Khouzam, R. B., Pohtb, P., \& Lobinski, R. (2011). Bioaccessibility of essential elements from white cheese, bread, fruit and vegetables. Talanta, 86, 425-428.

This article is protected by copyright. All rights reserved. 
Lagarda, M. J., Cilla, A., \& Barbera, R. (2016). CHAPTER 15 Bioaccessibility of Calcium in Legumes. In Calcium: Chemistry, Analysis, Function and Effects (pp. 237-255): The Royal Society of Chemistry.

National Health and Medical Research Council. (2017, 10 March 2017). Nutrient Reference Values for Australia and New Zealand. Retrieved from https://www.nrv.gov.au/nutrients

Petry, N., Egli, I., Gahutu, J. B., Tugirimana, P. L., Boy, E., \& Hurrell, R. (2012). Stable Iron Isotope Studies in Rwandese Women Indicate That the Common Bean Has Limited Potential as a Vehicle for Iron Biofortification. The Journal of Nutrition, 142(3), 492-497. doi:10.3945/jn.111.149286 ( Reviews in Food Science and Nutrition, 56(10), 1608-1619.

Pulse Australia. (2015). Pulses: Understanding Global Markets. Australian Pulse Bulletin. Retrieved from http://www.pulseaus.com.au/growing-pulses/publications/marketing-pulses\#major-pulseimporters

Quinteros, A., Farré, R., \& Lagarda, M. J. (2001). Optimization of iron speciation (soluble, ferrous and ferric) in beans, chickpeas and lentils. Food Chemistry, 75(3), 365-370. doi:10.1016/\$0308-8146(01)00214$\mathrm{x}$

Ramdath, D. D., \& Tsáo, R. (2012). Bioactives and Health Benefits of Lentils (Lens culinaris L.). In L. Yu, R. Tsao, \& F. Shahidi (Eds.), Cereals and Pulses: Nutraceutical Properties and Health Benefits (pp. 217 225). Oxford: Wiley-Blackwell.

Ramírez-Cárdenas, L., Leonel, A. J., Costa, N. M. B., \& Reis, F. P. (2010). Zinc bioavailability in different beans as affected by cultivar type and cooking conditions. Food Research International, 43(2), 573-581. doi:10.1016/j.foodres.2009.07.023

Sahuquillo, A., Barberá, R., \& Farré, R. (2003). Bioaccessibility of calcium, iron and zinc from three legume samples. Food / Nahrung, 47(6), 438-441. doi:10.1002/food.200390097

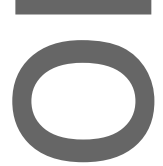

Sanders, E. R. (2012). Aseptic Laboratory Techniques: Plating Methods. Journal of Visualized Experiments : JOVE(63), 3064. doi:10.3791/3064

Singh, P.,Prasad, S., \& Aalbersberg, W. (2016). Bioavailability of Fe and Zn in selected legumes, cereals, meat and milk products consumed in Fiji. Food Chemistry, 207(Supplement C), 125-131. doi:10.1016/j.foodchem.2016.03.029

Sirisena, S., Ajlouni, S., \& Ng, K. (2017). Simulated gastrointestinal digestion and in vitro colonic fermentation of date (Phoenix dactylifera L.) seed polyphenols. International Journal of Food Science \& Technology, In press. doi:10.1111/ijfs.13599

This article is protected by copyright. All rights reserved. 
Sitrin, M. D. (2014). Absorption of Water-Soluble Vitamins and Minerals. In P. S. Leung (Ed.), The Gastrointestinal System: Gastrointestinal, Nutritional and Hepatobiliary Physiology (pp. 211-234). Dordrecht: Springer Netherlands.

Sparvoli, F., Bollini, R., \& Cominelli, E. (2015). Nutritional Value. In A. M. De Ron (Ed.), Grain Legumes (pp. 291-325). New York, NY: Springer New York.

Terry, M. E., \& Bonner, B. A. (1980). An Examination of Centrifugation as a Method of Extracting an Extracellular Solution from Peas, and Its Use for the Study of Indoleacetic Acid-induced Growth. Plant Physiology, 66(2), 321-325.

Tosh, S. M., \&Yada, S. (2010). Dietary fibres in pulse seeds and fractions: Characterization, functional attributes, and applications. Food Research International, 43(2), 450-460.

doi:10.1016/j.foodres.2009.09.005

United States Pharmacopeial Convention. (2009). Simulated Gastric Fluid. In United States Pharmacopeia (32 ed.). Rockville, MD: United States Pharmacopeial Convention.

Vaz Patto, M. C., Amarowicz, R., Aryee, A. N. A., Boye, J. I., Chung, H.-J., Martín-Cabrejas, M. A., \& Domoney, C. (2015). Achievements and Challenges in Improving the Nutritional Quality of Food Legumes. Critical Reviews in Plant Sciences, 34(1-3), 105-143. doi:10.1080/07352689.2014.897907

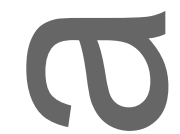

Victorian Government Data Directory. (2017). Victorian Soil Mapping. Retrieved from https://www.data.vic.gov.au/data/dataset/victorian-soil-type-mapping

Wang, N., \& Daun, J. K. (2006). Effects of variety and crude protein content on nutrients and anti-nutrients in lentils (Lens culinaris). Food Chemistry, 95(3), 493-502. doi:10.1016/j.foodchem.2005.02.001

Wang, N., Hatcher, D. W., \& Gawalko, E. J. (2008). Effect of variety and processing on nutrients and certain anti-nutrients in field peas (Pisum sativum). Food Chemistry, 111(1), 132-138.

doi:10.1016/j.foodchem.2008.03.047

Wang, N., Hatcher, D. W., Tyler, R. T., Toews, R., \& Gawalko, E. J. (2010). Effect of cooking on the composition of beans (Phaseolus vulgaris L.) and chickpeas (Cicer arietinum L.). Food Research International, 43(2), 589-594. doi:10.1016/j.foodres.2009.07.012

Welch, R. M., House,-W. A., Ortiz-Monasterio, I., \& Cheng, Z. (2005). Potential for Improving Bioavailable Zinc in Wheat Grain (Triticum Species) through Plant Breeding. Journal of Agricultural and Food Chemistry, 5B(6), 2176-2180. doi:10.1021/jf040238x

Wheal, M. S., Fowles, T. O., \& Palmer, L. T. (2011). A cost-effective acid digestion method using closed polypropylene tubes for inductively coupled plasma optical emission spectrometry (ICP-OES) analysis of plant essential elements. Analytical Methods, 3(12), 2854-2863. doi:10.1039/C1AY05430A

This article is protected by copyright. All rights reserved. 
WHO. (2010). Estimating appropriate levels of vitamins and minerals for food fortification programmes: The WHO Intake Monitoring, Assessment and Planning Program (IMAPP): meeting report. Retrieved from Geneva: http://www.who.int/nutrition/publications/micronutrients/9789241599603.pdf

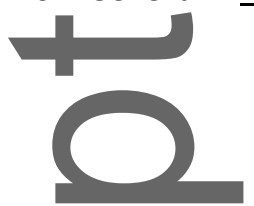

1

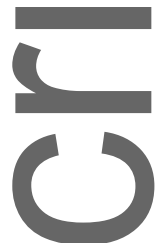

Tables

a) Table 1. Adult nutrient reference values for essential elements in Australia on a daily basis, relative to the amount found in $100 \mathrm{~g}$ pulses

\begin{tabular}{|c|c|c|c|}
\hline & $\begin{array}{l}\text { Estimated average } \\
\text { requirement (EAR) }\end{array}$ & $\begin{array}{l}\text { Recommended } \\
\text { daily intake (RDI) }\end{array}$ & $\begin{array}{l}\text { Amount found in } \\
100 \mathrm{~g} \text { dry pulses }\end{array}$ \\
\hline Iron (Fe) & $6-8 \mathrm{mg}$ & $8-18 \mathrm{mg}$ & $4.82-8.80 \mathrm{mg}$ \\
\hline Zinc $(Z n)$ & $6.5-12 \mathrm{mg}$ & $8-14 \mathrm{mg}$ & $2.62-3.96 \mathrm{mg}$ \\
\hline Calcium (C & $840-1100 \mathrm{mg}$ & $1100-1300 \mathrm{mg}$ & $59.3-165 \mathrm{mg}$ \\
\hline Magnesium (Mg) & $255-350 \mathrm{mg}$ & $310-420 \mathrm{mg}$ & $171-250.2 \mathrm{mg}$ \\
\hline Selenium (Se) & $50-60 \mu g$ & $60-70 \mu g$ & $171.6-223.2 \mathrm{ng}$ \\
\hline Copper (Cu) & $\mathrm{N} / \mathrm{A}(\mathrm{Al}: 1.2-1.7 \mathrm{mg})$ & $\mathrm{N} / \mathrm{A}$ & $0.77-1.43 \mathrm{mg}$ \\
\hline Phosphoro & $580 \mathrm{mg}$ & $1100 \mathrm{mg}$ & $317.4-426.5 \mathrm{mg}$ \\
\hline Potassium $(\mathrm{K})^{*}$ & N/A (Al: $2800-3800 \mathrm{mg})$ & $\mathrm{N} / \mathrm{A}$ & $970-2017.3 \mathrm{mg}$ \\
\hline Manganese $(M n)^{*}$ & $\mathrm{~N} / \mathrm{A}(\mathrm{Al}: 5-5.5 \mathrm{mg})$ & $\mathrm{N} / \mathrm{A}$ & $1.13-5.43 \mathrm{mg}$ \\
\hline
\end{tabular}

* Denotes insufficient current evidence to set an EAR or RDI. an Al (adequate intake) has thus been proposed based on median intakes from national dietary surveys.

Source: Chakravaty, 2003; Khanam \& Platel, 2016; National Health and Medical Research Council, 2017 
Table 2. Site characteristics (Bureau of Meteorology, 2016; Victorian Government Data Directory, 2017)

\begin{tabular}{lll}
\hline & Rokewood & Ouyen \\
\hline Soil type & Heavy red clay & Loamy sand \\
Minimum temperature & $5.7^{\circ} \mathrm{C}$ & $5.2^{\circ} \mathrm{C}$ \\
Maximum temperature & $25.6^{\circ} \mathrm{C}$ & $32.3^{\circ} \mathrm{C}$ \\
Approx. average rainfall (1994-2016) & $525 \mathrm{~mm}$ & $331 \mathrm{~mm}$ \\
Rainfall during the growing season & $412 \mathrm{~mm}$ & $213 \mathrm{~mm}$ \\
(April - December) & & \\
\hline
\end{tabular}

Table 3. Total mineral concentrations ( $\mathrm{mg} / 100 \mathrm{~g}$ dry weight) in the pulses studied. Data represent the mean of six measurements \pm SD

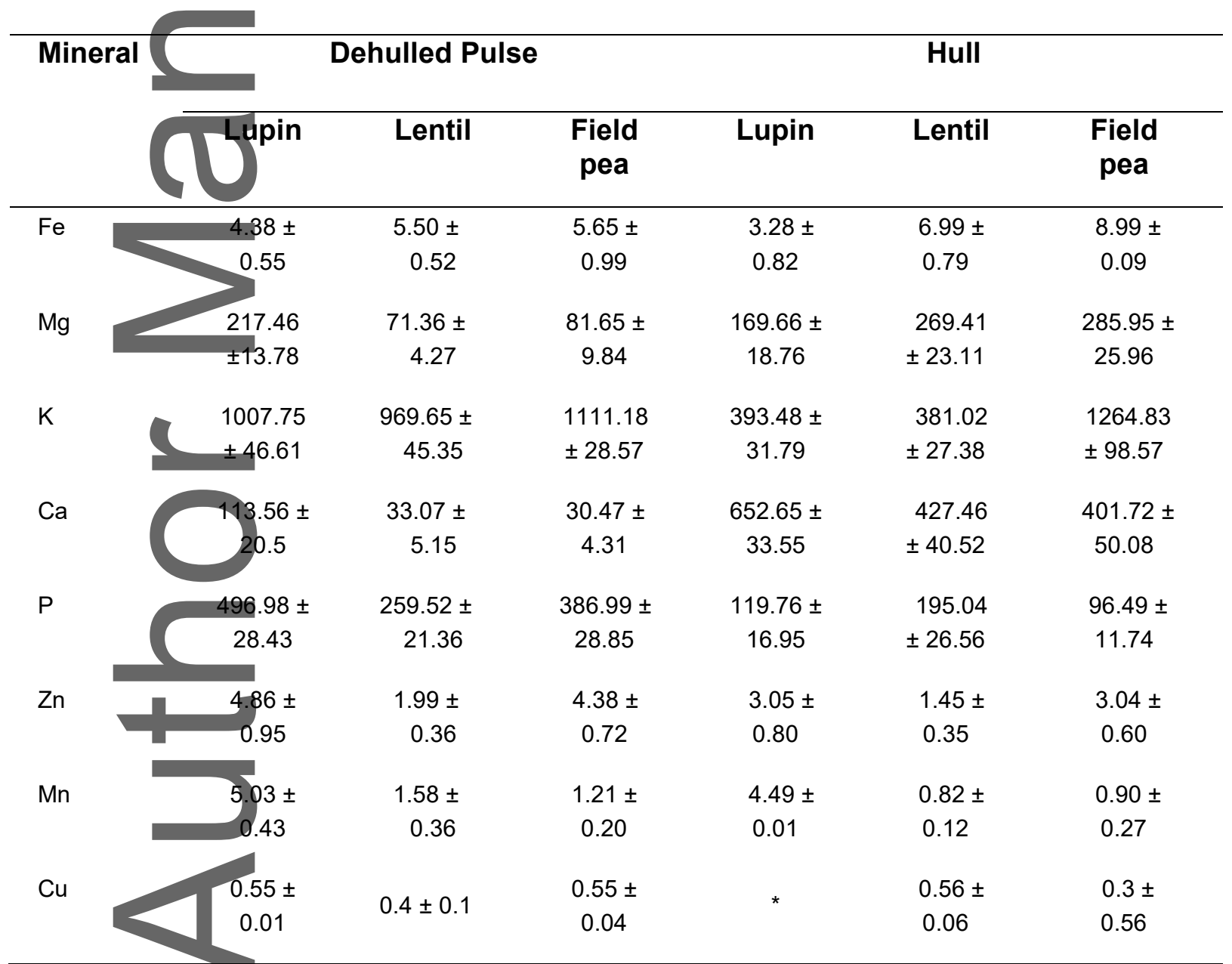

*denotes below detection limits of the ICP-OES at the amount quantified $(0.3 \pm 0.001 \mathrm{mg})$ 
Table 4. Percentage iron $(\mathrm{Fe})$ bioaccessibility relative to total quantity present in sample, values reported as means of six measurements \pm standard deviation

\begin{tabular}{|c|c|c|c|c|c|}
\hline \multirow[b]{2}{*}{ Pulse } & \multirow{2}{*}{$\begin{array}{l}\text { Digestion } \\
\text { state }\end{array}$} & \multicolumn{4}{|c|}{ \% Fe Bioaccessibility } \\
\hline & & $\begin{array}{l}\text { Gastric } \\
\text { digestion }\end{array}$ & $\begin{array}{l}\text { Intestinal } \\
\text { digestion }\end{array}$ & $\begin{array}{l}\text { Colonic } \\
\text { fermentation }\end{array}$ & $\begin{array}{l}\text { Total \% } \\
\text { Bioavailability }\end{array}$ \\
\hline \multirow[t]{4}{*}{ Lupin } & Fasted & $4.23 \pm 0.2^{b}$ & $<0.1^{\mathrm{a}}$ & $0.76 \pm 0.6^{a}$ & $4.99 \pm 0.8^{\mathrm{a}}$ \\
\hline & Fed & $3.27 \pm 0.5^{b}$ & $<0.1^{\mathrm{a}}$ & $4.71 \pm 1.4^{b}$ & $7.22 \pm 0.9^{b}$ \\
\hline & Fasted & $11.17 \pm 0.4^{\mathrm{a}}$ & $<0.1^{a}$ & $14.51 \pm 0.47^{\mathrm{C}}$ & $25.68 \pm 0.7^{\mathrm{C}}$ \\
\hline & Fed & $10.82 \pm 1.2^{\mathrm{a}}$ & $<0.1^{\mathrm{a}}$ & $13.2 \pm 0.95^{\mathrm{C}}$ & $24.02 \pm 0.8^{\mathrm{C}}$ \\
\hline \multirow[t]{4}{*}{ Lentils } & Fasted & $<0.1^{g}$ & $<0.1^{\mathrm{a}}$ & $<0.1^{\mathrm{d}}$ & $0.10^{\mathrm{d}}$ \\
\hline & Fed & $<0.1^{9}$ & $<0.1^{\mathrm{a}}$ & $<0.1^{\mathrm{d}}$ & $0.10^{\mathrm{d}}$ \\
\hline & Fasted & $5.2 \pm 0.3^{c}$ & $2.9 \pm 0.1^{b}$ & $17.47 \pm 1.1^{\mathrm{e}}$ & $25.57 \pm 1.4^{\mathrm{C}}$ \\
\hline & Fed & $7.4 \pm 1.1^{d}$ & $13.4 \pm 0.7^{c}$ & $21.53 \pm 1.38^{\dagger}$ & $42.33 \pm 2.3^{\mathrm{e}}$ \\
\hline \multirow{4}{*}{$\begin{array}{l}\text { Field } \\
\text { pea }\end{array}$} & Fasted & $0.9^{\mathrm{e}}$ & $<0.1^{\mathrm{a}}$ & $<0.1^{\mathrm{d}}$ & $0.99 \pm 0.57^{\dagger}$ \\
\hline & Fed & $1.2 \pm 0.1^{\dagger}$ & $<0.1^{\mathrm{a}}$ & $<0.1^{\mathrm{d}}$ & $1.23^{\dagger}$ \\
\hline & Fasted & $6.4 \pm 0.1^{\mathrm{d}}$ & $1.66 \pm 0.1^{\mathrm{d}}$ & $21.36 \pm 0.43^{\dagger}$ & $29.42 \pm 0.66^{9}$ \\
\hline & Fed & $9.5 \pm 2.1^{d}$ & $11.55 \pm 0.6^{\mathrm{e}}$ & $24.08 \pm 2.27^{\dagger}$ & $45.13 \pm 0.23^{h}$ \\
\hline
\end{tabular}

Means within each column followed by different superscript letters $\left({ }^{a, b, c, d}\right)$ are significantly different $(\mathrm{P}<0.05)$.

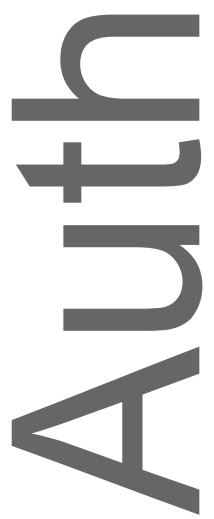

This article is protected by copyright. All rights reserved. 


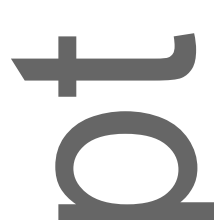

Table 5. Percentage magnesium $(\mathrm{Mg})$ bioaccessibility relative to total quantity present in sample, values reported as means of six measurements \pm standard deviation

\begin{tabular}{|c|c|c|c|c|c|}
\hline \multirow[b]{2}{*}{ Pulse } & \multirow{2}{*}{$\begin{array}{l}\text { Digestion } \\
\text { state }\end{array}$} & \multicolumn{4}{|c|}{$\%$ Mg Bioaccessibility } \\
\hline & & $\begin{array}{l}\text { Gastric } \\
\text { digestion }\end{array}$ & $\begin{array}{l}\text { Intestinal } \\
\text { digestion }\end{array}$ & $\begin{array}{l}\text { Colonic } \\
\text { fermentation }\end{array}$ & $\begin{array}{l}\text { Total \% } \\
\text { Bioavailability }\end{array}$ \\
\hline \multirow[t]{4}{*}{ Lupin } & Fasted & $17.75 \pm 0.2^{b}$ & $12.64 \pm 0.1^{\mathrm{a}}$ & $8.92 \pm 0.2^{\mathrm{a}}$ & $39.31 \pm 0.2^{\mathrm{a}}$ \\
\hline & Fed & $16.98 \pm 2.1^{b}$ & $14.87 \pm 1.1^{b}$ & $10.45 \pm 0.2^{b}$ & $42.3 \pm 1.4^{b}$ \\
\hline & Fasted & $29.19 \pm 4.4^{\mathrm{a}}$ & $14.36 \pm 1.8^{b}$ & $15.09 \pm 0.08^{c}$ & $58.64 \pm 2.7^{\mathrm{C}}$ \\
\hline & Fed & $30.22 \pm 3.7^{\mathrm{a}}$ & $14.33 \pm 0.8^{b}$ & $13.18 \pm 0.99^{d}$ & $57.73 \pm 0.2^{\mathrm{c}}$ \\
\hline \multirow[t]{4}{*}{ Lentils } & Fasted & $18.73 \pm 0.6^{\mathrm{d}}$ & $19.72 \pm 1^{d}$ & $4.46 \pm 0.53^{\mathrm{e}}$ & $42.91 \pm 0.8^{b}$ \\
\hline & Fed & $17.62 \pm 0.5^{\mathrm{d}}$ & $23.83 \pm 0.9^{\mathrm{e}}$ & $8.21 \pm 0.34^{\mathrm{a}}$ & $49.66 \pm 0.8^{\mathrm{d}}$ \\
\hline & Fasted & $23.11 \pm 1.8^{\mathrm{c}}$ & $11.6 \pm 3.1^{b}$ & $20.4 \pm 0.33^{\dagger}$ & $55.11 \pm 1.3^{\mathrm{e}}$ \\
\hline & Fed & $24.21 \pm 1.7^{\mathrm{C}}$ & $13.26 \pm 1.5^{b}$ & $22.58 \pm 1.92^{\dagger}$ & $60.05 \pm 1.96^{\mathrm{C}}$ \\
\hline \multirow{4}{*}{$\begin{array}{l}\text { Field } \\
\text { pea }\end{array}$} & Fasted & $19.9 \pm 1.1^{\dagger}$ & $5.11 \pm 0.3^{c}$ & $6.2 \pm 0.65^{9}$ & $31.21 \pm 1.5^{\dagger}$ \\
\hline & Fed & $16.66 \pm 0.4^{g}$ & $13.91 \pm 0.7^{b}$ & $5.87 \pm 0.39^{n}$ & $36.44 \pm 0.07^{9}$ \\
\hline & Fasted & $28.67 \pm 1.3^{\mathrm{e}}$ & $14.33 \pm 0.8^{b}$ & $27.46 \pm 2.38$ & $70.46 \pm 0.87^{h}$ \\
\hline & Fed & $29.78 \pm 0.1^{\mathrm{e}}$ & $19.91 \pm 0.2^{d}$ & $24.5 \pm 1.53^{\prime}$ & $74.19 \pm 0.14^{\prime}$ \\
\hline
\end{tabular}

Means within each column followed by different superscript letters $\left({ }^{a, b, c, d}\right)$ are significantly different $(P<0.05)$.

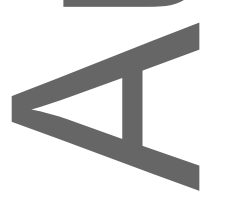


Table 6. Percentage potassium $(\mathrm{K})$ bioaccessibility relative to total quantity present in sample, values reported as means of six measurements \pm standard deviation

\begin{tabular}{|c|c|c|c|c|c|c|}
\hline \multirow[b]{2}{*}{ Pulse } & & \multirow{2}{*}{$\begin{array}{l}\text { Digestion } \\
\text { state }\end{array}$} & \multicolumn{4}{|c|}{ \% K Bioaccessibility } \\
\hline & & & $\begin{array}{l}\text { Gastric } \\
\text { digestion }\end{array}$ & $\begin{array}{l}\text { Intestinal } \\
\text { digestion }\end{array}$ & $\begin{array}{l}\text { Colonic } \\
\text { fermentation }\end{array}$ & $\begin{array}{l}\text { Total \% } \\
\text { Bioavailability }\end{array}$ \\
\hline \multirow[t]{4}{*}{ Lupin } & & Fasted & $40.95 \pm 1.1^{\mathrm{a}}$ & $<0.1^{a}$ & $15.35 \pm 2.85^{a}$ & $56.3 \pm 3.8^{a}$ \\
\hline & & Fed & $38.69 \pm 0.1^{\mathrm{a}}$ & $<0.1^{\mathrm{a}}$ & $14.57 \pm 1.96^{\mathrm{a}}$ & $53.26 \pm 1.7^{b}$ \\
\hline & & Fasted & $38.61 \pm 2.8^{\mathrm{a}}$ & $<0.1^{\mathrm{a}}$ & $22.66 \pm 0.03^{b}$ & $61.27 \pm 2.9^{b}$ \\
\hline & & Fed & $40.66 \pm 3.2^{\mathrm{a}}$ & $<0.1^{\mathrm{a}}$ & $21.21 \pm 1.42^{b}$ & $61.87 \pm 3.7^{b}$ \\
\hline \multirow[t]{4}{*}{ Lentils } & & Fasted & $10.4 \pm 0.3^{\mathrm{d}}$ & $<0.1^{\mathrm{a}}$ & $2.6 \pm 0.37^{c}$ & $13 \pm 0.5^{c}$ \\
\hline & & Fed & $9.6 \pm 0.4^{d}$ & $<0.1^{\mathrm{a}}$ & $7.14 \pm 0.86^{\mathrm{d}}$ & $16.74 \pm 0.6^{\mathrm{d}}$ \\
\hline & & Fasted & $24.82 \pm 2.4^{\mathrm{C}}$ & $7.6 \pm 0.2^{b}$ & $20.83 \pm 0.4^{b}$ & $53.25 \pm 0.4^{9}$ \\
\hline & & Fed & $25.61 \pm 0.8^{c}$ & $9.23 \pm 1.3^{\mathrm{C}}$ & $23.45 \pm 1.7^{b}$ & $58.29 \pm 1.9^{\mathrm{a}}$ \\
\hline \multirow{4}{*}{\multicolumn{2}{|c|}{$\begin{array}{l}\text { Field } \\
\text { pea }\end{array}$}} & Fasted & $17.7 \pm 0.6^{\mathrm{g}}$ & $2.7 \pm 0.39^{d}$ & $8.76 \pm 0.38^{e}$ & $29.16 \pm 0.35^{\mathrm{e}}$ \\
\hline & & Fed & $19.4 \pm 0.5^{\mathrm{d}}$ & $5.5 \pm 0.2^{\mathrm{e}}$ & $6.82 \pm 0.7^{\mathrm{d}}$ & $31.72 \pm 0.37^{\dagger}$ \\
\hline & & Fasted & $15.23 \pm 2.1^{\mathrm{e}}$ & $9.86 \pm 0.65^{\mathrm{C}}$ & $28.7 \pm 1.17^{\dagger}$ & $53.79 \pm 0.5^{9}$ \\
\hline & & Fed & $20.9 \pm 0.28^{\dagger}$ & $14.15 \pm 0.16^{\dagger}$ & $25.1 \pm 2.11^{\dagger}$ & $60.15 \pm 0.7^{\mathrm{a}}$ \\
\hline
\end{tabular}

Means within each column followed by different superscript letters $\left({ }^{a, b, c, d}\right)$ are significantly different $(P<0.05)$

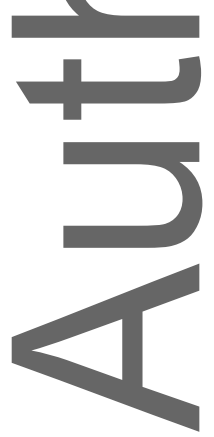

This article is protected by copyright. All rights reserved. 
Table 7. Percentage Calcium (Ca) bioaccessibility relative to total quantity present in sample, values reported as means of six measurements \pm standard deviation

\begin{tabular}{|c|c|c|c|c|c|}
\hline \multirow[b]{2}{*}{ Pulse } & \multirow{2}{*}{$\begin{array}{l}\text { Digestion } \\
\text { state }\end{array}$} & \multicolumn{4}{|c|}{ \% Ca Bioaccessibility } \\
\hline & & $\begin{array}{l}\text { Gastric } \\
\text { digestion }\end{array}$ & $\begin{array}{l}\text { Intestinal } \\
\text { digestion }\end{array}$ & $\begin{array}{l}\text { Colonic } \\
\text { fermentation }\end{array}$ & $\begin{array}{l}\text { Total \% } \\
\text { Bioavailability }\end{array}$ \\
\hline \multirow[t]{4}{*}{ Lupin } & Fasted & $5.2 \pm 0.1^{b}$ & $<0.1^{\mathrm{a}}$ & $4.78 \pm 0.77^{\mathrm{a}}$ & $9.98 \pm 0.5^{\mathrm{a}}$ \\
\hline & Fed & $6.79 \pm 0.7^{b}$ & $<0.1^{\mathrm{a}}$ & $6.04 \pm 0.33^{b}$ & $12.83 \pm 1.2^{b}$ \\
\hline & Fasted & $10.68 \pm 0.4^{\mathrm{a}}$ & $<0.1^{\mathrm{a}}$ & $39.87 \pm 0.04^{c}$ & $50.55 \pm 3.9^{C}$ \\
\hline & Fed & $12.57 \pm 3.1^{\mathrm{a}}$ & $<0.1^{\mathrm{a}}$ & $39.83 \pm 3.8^{\mathrm{C}}$ & $52.4 \pm 6.8^{c}$ \\
\hline \multirow[t]{4}{*}{ Lentils } & Fasted & $8.48 \pm 0.15^{9}$ & $10 \pm 0.2^{b}$ & $3.63 \pm 0.55^{\mathrm{a}}$ & $22.11 \pm 0.2^{\mathrm{d}}$ \\
\hline & Fed & $8.15 \pm 0.5^{9}$ & $13.58 \pm 0.4^{\mathrm{C}}$ & $5.5 \pm 1.3^{\mathrm{a}}$ & $27.23 \pm 0.8^{\mathrm{e}}$ \\
\hline & Fasted & $18.31 \pm 0.7^{\mathrm{C}}$ & $20.9 \pm 0.5^{\mathrm{d}}$ & $11.7 \pm 1.4^{\mathrm{e}}$ & $50.91 \pm 0.5^{c}$ \\
\hline & Fed & $20.35 \pm 1.6^{c}$ & $19.55 \pm 1.2^{\mathrm{d}}$ & $12.78 \pm 0.9^{\mathrm{e}}$ & $52.68 \pm 0.9^{C}$ \\
\hline \multirow{4}{*}{$\begin{array}{l}\text { Field } \\
\text { pea }\end{array}$} & Fasted & $11.11 \pm 0.2^{\mathrm{a}}$ & $<0.1^{\mathrm{a}}$ & $4.08 \pm 1.1^{\mathrm{a}}$ & $15.19 \pm 1.1^{\dagger}$ \\
\hline & Fed & $11.55 \pm 0.09^{b}$ & $<0.1^{\mathrm{a}}$ & $3.81 \pm 0.33^{\mathrm{a}}$ & $15.36 \pm 0.55^{\dagger}$ \\
\hline & Fasted & $11.11 \pm 0.2^{\mathrm{a}}$ & $<0.1^{\mathrm{a}}$ & $24.92 \pm 0.3^{\dagger}$ & $36.03 \pm 1.2^{g}$ \\
\hline & Fed & $21.9 \pm 3.12^{\dagger}$ & $<0.1^{\mathrm{a}}$ & $30.6 \pm 2.21^{9}$ & $52.5 \pm 3.08^{\mathrm{C}}$ \\
\hline
\end{tabular}

Means within each column followed by different superscript letters $\left({ }^{a, b, c, d}\right)$ are significantly different $(\mathrm{P}<0.05)$.

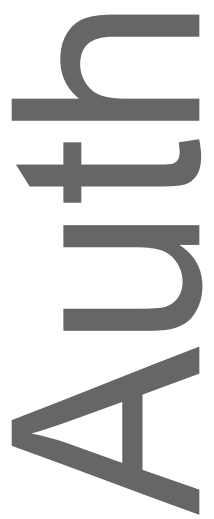

This article is protected by copyright. All rights reserved. 
Table 8. Percentage Phosphorous $(P)$ bioaccessibility relative to total quantity present in sample, values reported as means of six measurements \pm standard deviation

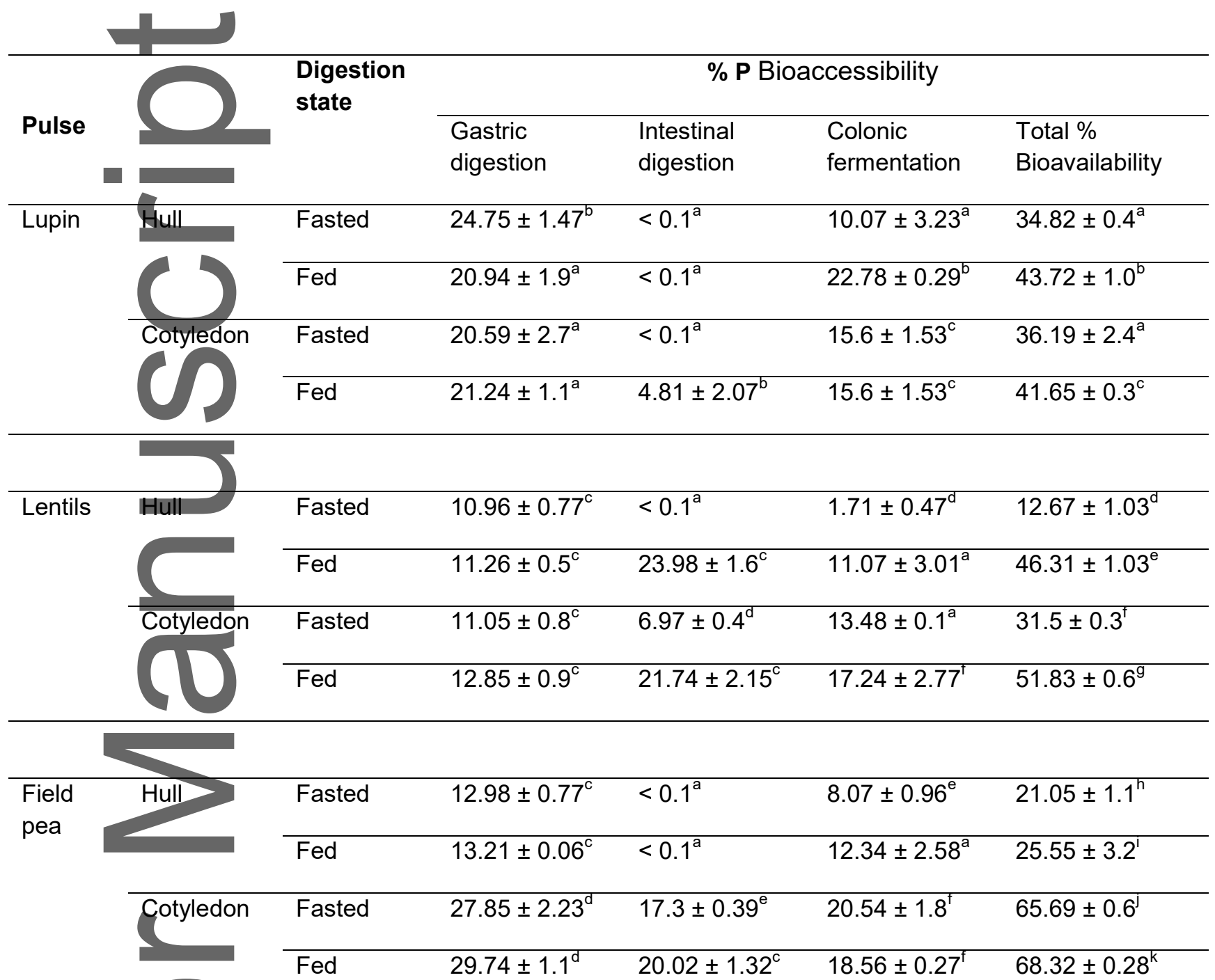

Means within each column followed by different superscript letters $\left({ }^{a, b, c, d}\right)$ are significantly different $(\mathrm{P}<0.05)$.

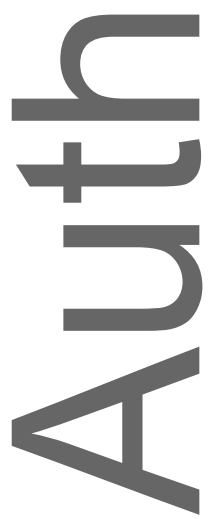

This article is protected by copyright. All rights reserved. 
Table 9. Percentage Zinc (Zn) bioaccessibility relative to total quantity present in sample, values reported as means of six measurements \pm standard deviation

\begin{tabular}{|c|c|c|c|c|c|}
\hline \multirow[b]{2}{*}{ Pulse } & \multirow{2}{*}{$\begin{array}{l}\text { Digestion } \\
\text { state }\end{array}$} & \multicolumn{4}{|c|}{ \% Zn Bioaccessibility } \\
\hline & & $\begin{array}{l}\text { Gastric } \\
\text { digestion }\end{array}$ & $\begin{array}{l}\text { Intestinal } \\
\text { digestion }\end{array}$ & $\begin{array}{l}\text { Colonic } \\
\text { fermentation }\end{array}$ & $\begin{array}{l}\text { Total \% } \\
\text { Bioavailability }\end{array}$ \\
\hline \multirow[t]{4}{*}{ Lupin } & Fasted & $0.31 \pm 0.04^{b}$ & $<0.1^{\mathrm{a}}$ & $0.04 \pm 0.03^{\mathrm{a}}$ & $0.35 \pm 0.03^{\mathrm{a}}$ \\
\hline & Fed & $0.32 \pm 0.04^{b}$ & $<0.1^{\mathrm{a}}$ & $0.09 \pm 0.01^{b}$ & $0.41 \pm 0.05^{\mathrm{a}}$ \\
\hline & Fasted & $24.23 \pm 2.53^{\mathrm{a}}$ & $0.55 \pm 0.57^{b}$ & $14.6 \pm 2.7^{\mathrm{C}}$ & $39.38 \pm 0.2^{b}$ \\
\hline & Fed & $21.83 \pm 0.8^{\mathrm{a}}$ & $<0.1^{\mathrm{a}}$ & $3.26 \pm 0.9^{d}$ & $25.09 \pm 0.3^{c}$ \\
\hline \multirow[t]{4}{*}{ Lentils } & Fasted & $10.1 \pm 0.56^{c}$ & $2.04 \pm 0.09^{C}$ & $<0.1^{\mathrm{e}}$ & $12.14 \pm 0.4^{\mathrm{d}}$ \\
\hline & Fed & $10.33 \pm 0.56^{c}$ & $2.79 \pm 0.24^{\mathrm{C}}$ & $<0.1^{\mathrm{e}}$ & $13.12 \pm 0.4^{\mathrm{e}}$ \\
\hline & Fasted & $10.27 \pm 0.3^{c}$ & $9.42 \pm 0.14^{\mathrm{d}}$ & $7.36 \pm 0.4^{\dagger}$ & $27.05 \pm 0.98^{\dagger}$ \\
\hline & Fed & $10.52 \pm 0.6^{c}$ & $6.03 \pm 0.38^{\mathrm{e}}$ & $7.75 \pm 1.06^{\dagger}$ & $24.3 \pm 1.0^{C}$ \\
\hline \multirow{4}{*}{$\begin{array}{l}\text { Field } \\
\text { pea }\end{array}$} & Fasted & $21.62 \pm 1.8^{\mathrm{e}}$ & $1.64 \pm 0.9^{\dagger}$ & $<0.1^{\mathrm{e}}$ & $23.26 \pm 0.9^{C}$ \\
\hline & Fed & $21.78 \pm 1.17^{\mathrm{e}}$ & $1.73 \pm 1.07^{\dagger}$ & $<0.1^{\mathrm{e}}$ & $23.51 \pm 0.44^{\mathrm{C}}$ \\
\hline & Fasted & $18.88 \pm 0.91^{\mathrm{d}}$ & $7.26 \pm 1.26^{9}$ & $6.18 \pm 0.84^{\dagger}$ & $32.32 \pm 0.2^{g}$ \\
\hline & Fed & $19.66 \pm 1.17^{\mathrm{d}}$ & $10.81 \pm 0.2^{h}$ & $7.08 \pm 0.99^{\dagger}$ & $37.55 \pm 0.35^{h}$ \\
\hline
\end{tabular}

Means within each column followed by different superscript letters $\left({ }^{a, b, c, d}\right)$ are significantly different $(\mathrm{P}<0.05)$.

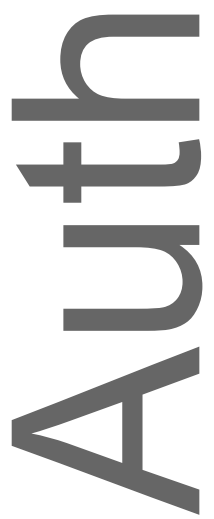

This article is protected by copyright. All rights reserved. 
Table 10. Percentage Manganese (Mn) bioaccessibility relative to total quantity present in sample, values reported as means of six measurements \pm standard deviation

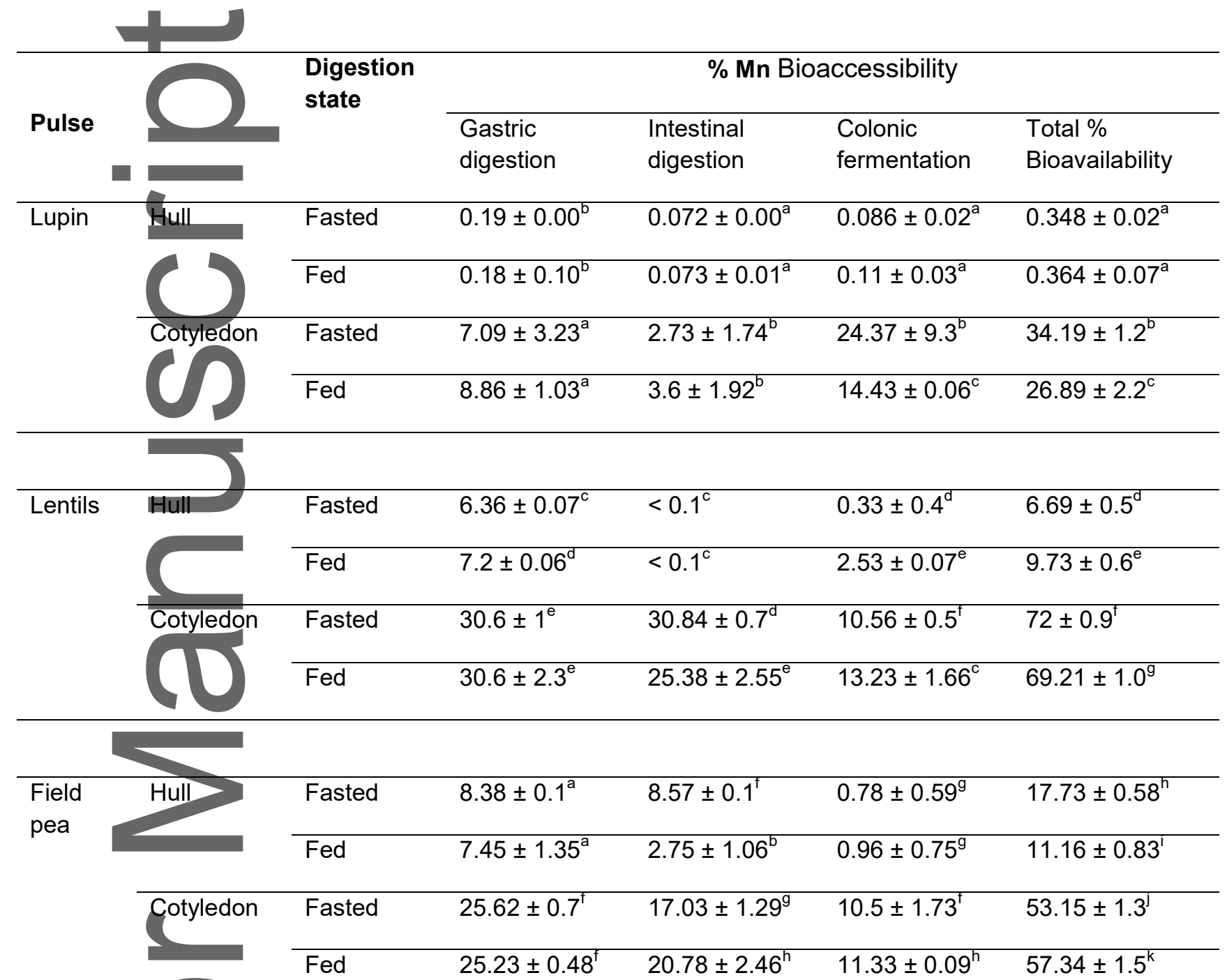

Means within each column followed by different superscript letters $\left({ }^{a, b, c, d}\right)$ are significantly different $(\mathrm{P}<0.05)$.

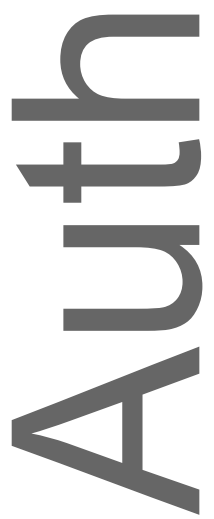

This article is protected by copyright. All rights reserved. 
Table 11. Percentage Copper $(\mathrm{Cu})$ bioaccessibility relative to total quantity present in sample, values reported as means of six measurements \pm standard deviation

\begin{tabular}{|c|c|c|c|c|c|c|}
\hline \multirow[b]{2}{*}{ Pulse } & \multirow[b]{2}{*}{ 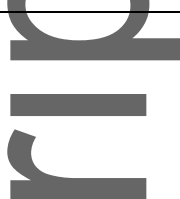 } & \multirow{2}{*}{$\begin{array}{l}\text { Digestion } \\
\text { state }\end{array}$} & \multicolumn{4}{|c|}{ \% Cu Bioaccessibility } \\
\hline & & & $\begin{array}{l}\text { Gastric } \\
\text { digestion }\end{array}$ & $\begin{array}{l}\text { Intestinal } \\
\text { digestion }\end{array}$ & $\begin{array}{l}\text { Colonic } \\
\text { fermentation }\end{array}$ & $\begin{array}{l}\text { Total \% } \\
\text { Bioavailability }\end{array}$ \\
\hline \multirow[t]{4}{*}{ Lupin } & & Fasted & $<0.1^{\mathrm{a}}$ & $<0.1^{\mathrm{a}}$ & $<0.1^{\mathrm{a}}$ & $<0.1^{\mathrm{a}}$ \\
\hline & & Fed & $<0.1^{a}$ & $<0.1^{\mathrm{a}}$ & $<0.1^{a}$ & $<0.1^{\mathrm{a}}$ \\
\hline & & Fasted & $60.62 \pm 3.73^{b}$ & $<0.1^{\mathrm{a}}$ & $<0.1^{\mathrm{a}}$ & $60.62 \pm 3.7^{b}$ \\
\hline & & Fed & $54.74 \pm 9.8^{b}$ & $1.97 \pm 1.92^{b}$ & $<0.1^{\mathrm{a}}$ & $56.71 \pm 2.2^{b}$ \\
\hline \multirow[t]{4}{*}{ Lentils } & & Fasted & $29.3 \pm 1.45^{\mathrm{C}}$ & $20.61 \pm 4.35^{c}$ & $<0.1^{\mathrm{a}}$ & $49.91 \pm 1.0^{C}$ \\
\hline & & Fed & $29.3 \pm 1.29^{C}$ & $27.97 \pm 1.93^{\mathrm{d}}$ & $<0.1^{\mathrm{a}}$ & $57.27 \pm 1.1^{b}$ \\
\hline & & Fasted & $40.84 \pm 2.34^{\mathrm{d}}$ & $27.5 \pm 2.31^{\mathrm{d}}$ & $<0.1^{\mathrm{a}}$ & $68.34 \pm 1.6^{\mathrm{d}}$ \\
\hline & & Fed & $43.62 \pm 0.49^{d}$ & $24.04 \pm 0.08^{c}$ & $<0.1^{\mathrm{a}}$ & $67.66 \pm 0.8^{\mathrm{d}}$ \\
\hline \multirow{4}{*}{\multicolumn{2}{|c|}{$\begin{array}{l}\text { Field } \\
\text { pea }\end{array}$}} & Fasted & $51.87 \pm 0.18^{\dagger}$ & $15.87 \pm 0.54^{\mathrm{e}}$ & $<0.1^{a}$ & $67.74 \pm 1.8^{\mathrm{d}}$ \\
\hline & & Fed & $48.06 \pm 3.18^{\dagger}$ & $10.26 \pm 1.09^{g}$ & $<0.1^{a}$ & $58.32 \pm 0.07^{b}$ \\
\hline & & Fasted & $45.76 \pm 2.28^{\mathrm{d}}$ & $22.44 \pm 0.71^{\dagger}$ & $5.7 \pm 0.35^{b}$ & $73.9 \pm 1.7^{\mathrm{e}}$ \\
\hline & & Fed & $47.57 \pm 2.81^{\mathrm{d}}$ & $28.46 \pm 1.45^{\mathrm{d}}$ & $4.05 \pm 0.36^{c}$ & $80.08 \pm 2.0^{\dagger}$ \\
\hline
\end{tabular}

Means within each column followed by different superscript letters $\left({ }^{a, b, c, d}\right)$ are significantly different $(P<0.05)$.

*denotes no detectable levels of Cu present in the original sample

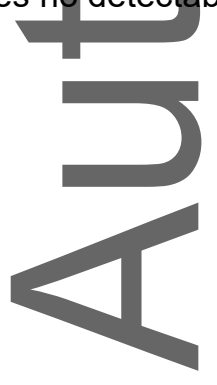

This article is protected by copyright. All rights reserved. 


\section{University Library}

\section{- M M N E R VA A gateway to Melbourne's research publications}

Minerva Access is the Institutional Repository of The University of Melbourne

Author/s:

Zhang, YY;Panozzo, J;Hall, MS;Ajlouni, S

Title:

Bioaccessibility of Some Essential Minerals in Three Selected Australian Pulse Varieties Using an In Vitro Gastrointestinal Digestion Model

Date:

2018-11-01

Citation:

Zhang, Y. Y., Panozzo, J., Hall, M. S. \& Ajlouni, S. (2018). Bioaccessibility of Some Essential Minerals in Three Selected Australian Pulse Varieties Using an In Vitro Gastrointestinal Digestion Model. JOURNAL OF FOOD SCIENCE, 83 (11), pp.2873-2881. https:// doi.org/10.1111/1750-3841.14377.

Persistent Link:

http://hdl.handle.net/11343/284682 